\title{
A DIACHRONIC ONOMASIOLOGICAL APPROACH TO EARLY BANTU OIL PALM VOCABULARY ${ }^{*}$
}

\author{
Koen Bostoen \\ Royal Museum for Central Africa Tervuren \\ Université Libre de Bruxelles
}

\begin{abstract}
Despite its ancient and long-lasting importance to sub-Saharan African economies, there has been no systematic attempt to reconstruct Proto-Bantu vocabulary referring to the oil palm (Elaeis guineensis Jacq.). Scholars have identified four common noun stems for 'oil palm', i.e. *-bídà (cl. 5/6, 7/8), '-bá (cl. 5/6), *-gàdí (cl. 9/10), and *-téndé (cl. 3/4) but determined the stems' geographic distributions within the Bantu domain to be insufficiently widespread to reflect a Proto-Bantu origin. From the wider perspective of Niger-Congo, certain of these nouns undoubtedly reconstruct to a level higher than Narrow Bantu. This paper presents an onomasiological approach to the earliest Bantu 'oil palm' vocabulary, offering a diachronic semantic analysis of the main noun stems, and an evaluation of the historical implications of their current-day distribution, both with respect to each other and in the light of the available Niger-Congo data.
\end{abstract}

\section{Introduction.}

The oil palm (Elaeis guineensis Jacq.) is a tree crop, belonging to the Palmae or Arecaceae, a very ancient family of mainly tropical and subtropical plants (Pur-

\footnotetext{
* The research for this paper is funded by the Belgian Federal Science Policy Office and contributes to the "Words and Plants" project of the Linguistics service of the Royal Museum for Central Africa. It is based on lexical data collected for the "Sakasaka: Comparative Bantu Food Crop Vocabulary" database, developed by my colleague Jacky Maniacky and myself. My thanks go to Odette Ambourouè, Lee Bickmore, Roger Blench, Caroline Dedisa, Kathryn de Luna, Jacky Maniacky, Jeff Marck, Yves Moñino, André Motingea, Gérard Philippson and Martin Walsh for their comments and/or sharing of information.
} 
seglove 1972: 416-7). This family includes other useful and well-known plants of tropical Africa, such as the betel-palm (Areca catechu Linn.), the coconut (Cocos nucifera Linn.), the borassus-palm (Borassus aethiopum Mart.), the raffia-palm (Raphia spp.), the date-palm (Phoenix dactylifera Linn.) and the Senegal datepalm (Phoenix reclinata Jacq.), also called wild, swamp or dwarf date-palm (Burkill 1997). The genus name Elaeis is derived from the Greek word elaion, 'oil', while the species name shows that Jacquin, who coined it, attributed the origin of the oil palm to the Guinea Coast (Hartley 1967: 37).

The geographic distribution of the oil palm is seen in Map 1, adapted from from Hartley (1967: 7), where dots indicate sporadic palm groves, and doublehatching indicates a high density of oil palm. ${ }^{1}$

\section{Map 1: Distribution of the oil palm}

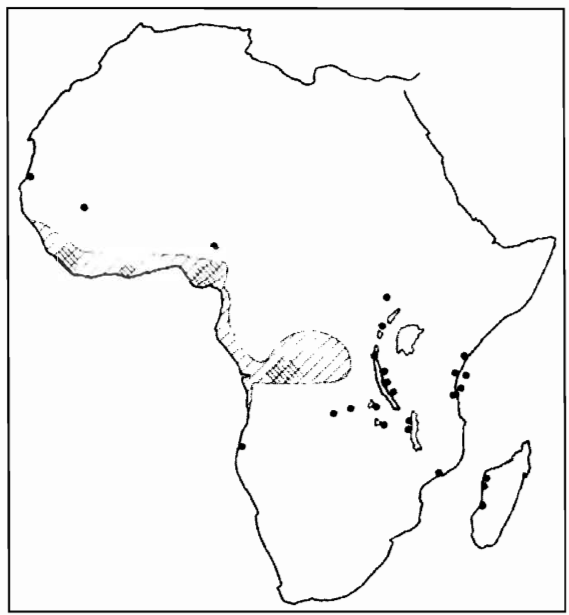

On the western side of the continent, one can observe natural palm groves between $16^{\circ} \mathrm{N}$ and $10^{\circ} \mathrm{S}$, but the real palm belt of Africa runs from the Fouta Jallon district of Guinea through Sierra Leone, Liberia, the Ivory Coast, Ghana, Togo, Benin, Nigeria, Cameroon and Gabon into the two Congos and even northern Angola. In eastern Africa, its distribution is much more scattered, since most of East and South-East Africa is too dry to support the species.

As one of the major indigenous oil-yielding plants of Africa, the oil palm's economic significance is both diverse and old. Palynological studies indicate that

' We thank Blackwell Scientific for permission to reproduce this map. 
its presence in the natural vegetation of some parts of Africa is extremely ancient, with evidence for the oil palm in Guinea (Conakry) dating from 54.8 to 33.7 million years ago (Maley 1999; Maley \& Chepstow-Lusty 2001; Sowunmi 1999). Moreover, archaeologists have uncovered its endocarp, often carbonised, in several sites of Western and Central Africa, which suggests that human exploitation of the oil palm dates as far back as 5,000 BP (see for instance Sowunmi (1999) for an overview of archaeological finds of palm-nut husks). The products of the oil palm have considerable commercial value, but also play an important role in African subsistence economies, providing palm oil, palm kernel oil, palm wine, palm harts, leaves for thatching, and petioles and rachises for fencing (Cornet 2001: 841-2; Purseglove 1972: 479-81; Sowunmi 1999: 201).

The economic relevance of the oil palm for a given society tends to be reflected in the amount of specialised vocabulary related to it. In Mongo (C61), to cite only one example, Hulstaert (1966) noted no less than 40 specific terms, referring to aspects as diverse as the different types of oil palms (chiefly according to age), the parts of the tree, the bunch and its parts, the different kinds of fruits (according to their appearance or their place on the bunch), and, finally, some derived products. However, the existence of a diverse vocabulary does not necessarily imply its documentation. Thus, the amount of terminology available to the researcher varies from one language to another. Frequently, one finds only the generic plant name (sometimes without notation of which kind of palm tree), the name of the fruit and, occasionally, the names of general oil palm products. Although a comparative lexical study of more precise vocabulary might be enlightening with respect to the history of oil palm exploitation, as a result of the uneven documentation of oil palm vocabulary, this paper will focus on the generic names of the tree itself and its fruits. Other types of palms will not be considered systematically either, although future research should deal in more detail with the lexical links that exist between the oil palm and other species.

\section{Previous Reconstructions of Generic Bantu Oil Palm Names.}

Although Kölle (1854) lists various Bantu nouns for palm-tree in his Polyglotta Africana, Meinhof (1910: 249) was the first to reconstruct the noun stem -tende, 'Palme' on the basis of reflexes in Swahili (G42), Kongo (H16), Herero (R31) and Duala (A24). Meinhof and van Warmelo (1932: 246) adopted this reconstruction. Bourquin (1923: 230) mentions -tende together with the stems -kindu and -lala, but the latter two refer to other kinds of palm trees, the Senegal date palm (Phoenix reclinata Jacq.) (cf. Bastin et al. 2003) and certain species of fan 
palm (Hyphaene spp.), e.g. Venda (S21) mulala, 'fan palm (Hyphaene natalensis Kunze)' (van Warmelo 1989: 221). Meeussen (1969) also reconstructed *-kindu (cl. 3), *-téndé (cl. 3; 9) and *-dada. However, the most comprehensive account of reconstructed noun stems directly referring to the oil palm can be found in Guthrie (1967-1971), and was later adopted by Bastin et al. (2003): *-bá (cl. 5/6; C.S. 1), *-bịdà (cl. 5/6, 7/8; C.S. 140), *-gàdí (cl. 9/10; C.S. 767 + C.S. 768 with the meaning 'nut of oil-palm') and *-téndé (cl. 3/4; C.S. 1712). ${ }^{2}$ In his comment to C.S. 140, Guthrie (1967-1971) affirms:

This belongs to a group of three synonymous C.S., the others being C.S. 1 and 767. Apart from one or two entries from zone $\mathrm{D}$, which could be due to intrusion, the whole group has a western distribution, and this no doubt reflects the fact that the oil-palm is a more important factor in the economy in the west than elsewhere in the Bantu field. From the relative spread of the three C.S. it seems probable that the PB-A (= West Bantu, K.B.) item was *-bịdà, which was replaced in the central and southern parts of the region by ${ }^{*}$-bá on the western side and *-gàdí on the eastern. [vol 3, p. 49]

With respect to *-téndé, Guthrie (1967-1971) doubts whether this C.S. consists of direct cognates, since the meanings of the five entries diverge. In an article on the contributions from comparative Bantu studies to the prehistory of Africa, Guthrie (1970) discusses other food crops, but does not consider the historical role of the oil palm. Furthermore, neither the historical interpretation by Dalby (1976) of Guthrie nor the historical linguistic research of Philippson \& Bahuchet (1994-95) on cultivated crops in the Bantu domain investigate the oil palm. Beyond Narrow Bantu, on the contrary, linguistic evidence for the history of oil palm exploitation has gained more attention (see for example Blench (forthcoming), Connell (1998), and Williamson (1970, 1993) for lexical reconstructions in other Niger-Congo language groups). This paper will reassess the Guthrie (1967-

2 In this paper, the 7-vowel system ( $i$ e e a o $v u$ ) of Bastin et al. (2003) is adopted for the representation of reconstructed forms, unless I explicitly refer to reconstructions of nther authors, who may use other notation systems (e.g. i i e a o $u$ u). Similarly, apart from the reconstructions by authors who always use the * sign, reconstructions preceded by * are hypothesized to go back to Proto-Bantu, while ${ }^{\circ}$ refers to uncertain and/or regional Bantu reconstructions. Abbreviations used in this text: $\mathrm{BP}=$ before present; $\mathrm{cl}$. $=$ class; $\mathrm{C}_{1 / 2}=$ first or second consonant of a noun stem or verb root; $\mathrm{C} . \mathrm{S}$. = comparative series; $\mathrm{H}=$ high tone; $\mathrm{L}=$ low tone; $\mathrm{NP}=$ noun prefix; $\mathrm{PB}=$ Proto-Bantu; $(\mathrm{P}) \mathrm{NC}=($ Proto- $)$ Niger-Congo; $(\mathrm{P}) \mathrm{DC}=($ Proto- $)$ Delta-Cross; $\mathrm{V}_{1 / 2}=$ first or second vowel of a noun stem or verb root. 
1971) hypothesis, taking into consideration additional (narrow) Bantu data and recent non-Bantu Niger-Congo reconstructions.

\section{Analysis and Distribution of the Bantu Comparative Series.}

In this section, I will present a succinct analysis of each of the main 'oil palm' comparative series. Although phonological aspects will be treated if necessary, this analysis will focus on their (morpho-)semantic properties. I will also consider their geographic distribution as represented on the isogloss maps given throughout the article.

$3.1^{\circ}$-bá, 'oil palm', 'palm nut'. Table 1 presents a reflex of ${ }^{\circ}-b a ́$, 'oil palm' from each of the Guthrie zones in which it is attested.

Table 1: Reflexes of ${ }^{\circ}-b a ́$, 'oil palm', 'palm nut'

B86 Dzing di-ba cl. 5-6 'palmier élais' (Mertens 1939:

17, 203)

C35b Bolia ibá cl. 5-6 'Elaeis guine- (Ngila Bompeti ensis Jacq.' 2000: 97)

H41 Mbala $b a \quad$ cl. 5-6 'nom générique (Mudindaambi des palmiers; 1977: 37) palmier à l'huile'

R11 Umbundu eva cl. 5-6 nome comum (Le Guennec \& das Palmácias Valente 1972: 460)

As regards the phonological shape and the tone of ${ }^{\circ}-b a a^{2}$ the reconstruction of the monosyllabic noun stem proposed by Guthrie (1967-1971) is confirmed by our data. The $C_{1} b$ has a direct reflex in most of the languages. With respect to the $V_{1}$, in all languages, the noun stems attest the vowel $a$. In Songye (L23), Stappers (1984: 36) mentions èbwé, 'palm tree', but since diphthongisation is not a common process in this language, one doubts whether èbwé is a reflex of ${ }^{\circ}-b a ́$. Finally, the reconstructed high tone is directly reflected in almost all languages in which the reflex is available with tonal notation.

With respect to noun class, the reflexes of ${ }^{\circ}-b a$ can, roughly speaking, be subdivided in two groups, those which belong to cl. 5-6 and those which belong 
to either cl. 11-10 or cl. 9-10. ${ }^{3}$ This subdivision is morphosemantic because the variation of noun prefixes systematically corresponds to a change in meaning. While ${ }^{\circ}-b a$ reflexes occurring in cl. 5-6 designate the tree itself, those preceded by $\mathrm{NP}_{11-10}$ or $\mathrm{NP}_{9-10}$ refer to its fruits. ${ }^{4}$ Except in the $\mathrm{C} 80$ languages, where one only finds reflexes of the latter kind, nouns for the palm nut generally co-exist with nouns referring to the oil palm itself. Such is the case in Boma (B82), Tsong (B85d), Ntomba (C35a), Bolia (C35b) and Tetela (C71). ${ }^{5}$ This is not always true the other way around. As will be shown below, several languages which have a cl. 5-6 reflex for the tree itself use another noun stem for its fruit. Based on the available Bantu data, the meaning 'palm nut' of the noun stem '-bá can be considered the result of a semantic evolution by means of simple noun class variation. This semantic shift seems to be secondary, since it is only attested in the $\mathrm{B} 50, \mathrm{~B} 60$, and B80 languages and in the C30, C70, and C80 Inner Congo Basin languages.

Semantically, apart from the morphosemantic subdivision just treated, the present-day ${ }^{\circ}-b a$ reflexes commonly refer to the oil palm, at least insofar as documented translations allow one to distinguish. For some languages, even though the kind of palm tree is not specified, e.g. Yoombe (H12b) liba (H-B), 'palmier' (Mabiala 1992), comparison with closely related languages suggests that a reflex probably refers to the oil palm. In other languages, on the contrary, it is clearly stated that the reflex serves as a generic noun for different species of palm trees, e.g. Ntandu (H16g) 'nom collectif des Palmiers à stipe' (Daeleman \& Pauwels 1983: 207), Umbundu (R11) eva, 'nome comum das Palmácias' (Le

${ }^{3}$ One exception to this "rule" is the Mbere (B61) reflex oba 'E. var. nigrescens' (RapondaWalker \& Sillans 1961: 335), which probably belongs to cl. 3-4, as several other tree names do (cf. Adam 1954: 29). Guthrie (1967-1971; C.S. 1) gives the Mbere (B61) reflex koba (cl. 7-8).

${ }^{4}$ From a comparative point of view, it is very ordinary in Bantu to observe the co-occurrence of the noun class pairings 11-10 and 9-10. Cl. 9 being much more common than $\mathrm{cl}$. 11, nouns originally occurring in the latter are frequently reclassified in the former, since both generally take their plural in cl. 10 (Bastin 1985: 14; Grégoire 1976: 7). I described this class shift in some detail for the PB etymon *-bìgá, 'pot' (Bostoen 2005: 199-200).

${ }^{5}$ In Bushong (C83), the name of the tree itself is fáam (Vansina 1959: 95), in Wongo (B85) sa: mpa (Burssens 1993: 472), and in Ndengese (C81) toko (Goemaere n.d.: 40). The latter noun stem also refers to the oil palm in Tetela (C71) and in certain C50 languages, such as Linga, Lyombo (C53), and Kele (C55). In Mongo (C61), it designates, more precisely, a young palm tree (Hulstaert 1966: 131). In Tetela (C71) and Leke (C14), it is also used to refer to the palm grove. 
Guennec \& Valente 1972: 460). In Ntandu (H16g), bá can be modified by three nouns to refer to the oil palm specifically: bá dínsaamba, bá dikísáambu, and bá dingási (Daeleman \& Pauwels 1983: 207). The noun nsáamba designates the wine extracted from the male inflorescence, while kisáambu and ngási refer to the palm nut (ibid.: 208). As seen in the Mbala (H41) example ba, 'nom générique des palmiers; palmier à l'huile' (Mudindaambi 1977: 37), the reflex may also be a generic noun, refering simultaneously to one precise species as the most prototypical representative of the category, i.e. the oil palm. ${ }^{6}$

It should be noted, however, that the available data do not really allow one to assess the conceptual perimeters of the category covered by the generic noun. It is rather unlikely that in the mind of a native speaker the conceptual range of the ${ }^{\circ}-b a$ reflex would exactly coincide with the botanically determined Palmae family or certain of its genera. Unpublished data from Bembe (H11) illustrate this point. The noun bá (cl. 5-6) seems to function as a generic noun for all palm trees bearing nuts, including the oil palm, the coconut (bá dyá mindélé, (litt.) 'the Whiteman's palm tree') and the raffia-palm ((bá dyá) muhokó) (Jacky Maniacky pers. comm.). ${ }^{7}$

Certain sources specify the variety of oil palm to which the ${ }^{\circ}-b a$ reflex refers. According to Raponda-Walker \& Sillans (1961: 335), the Duma (B51), Mbere (B61) and Ndumu (B66) reflexes refer particularly to the nigrescens variety. In botanical literature, oil palms are classified in two ways: according to the external appearance of the fruit (nigrescens or black-fruited, viriscens or greenfruited, albescens or white-fruited variety) and according to the thickness of the fruit's pericarp (dura or thick-shelled, tenera or thin-shelled, pisifera or shell-less variety), which may give the following combinations: dura nigrescens, tenera nigrescens, pisifera nigrescens; dura virescens, tenera virescens, pisifera virescens; dura albescens (Cornet 2001; Hartley 1967).

Although no such specifications are found in other languages, it is not surprising to note that the nigrescens type is referred to by a common Bantu noun, since it is the most common fruit type. In these languages, the less common virescens type has its own specific name, i.e. -tono (cl. 3-4) (Raponda-Walker \& Sillans 1961: 336). It must be a fairly local noun stem, Pove (B22c) being the only other language where it is also attested: -tònó (cl. 15-10), 'palmier Elaeis var. vi-

${ }^{6}$ In order to refer to other species of palm trees, the generic noun needs to be determined, e.g. ba dipudu 'cocotier' (Mudindaambi 1977: 37), cf. Ntandu (H16g) bá dínkáándi, bá dímputu 'cocotier' (Daeleman \& Pauwels 1983: 207).

${ }^{7}$ Cf. Swartenbroeckx (1973: 310): màyóko, 'raphias géants pour maléké'. 
rescens Jacq.' (Mickala Manfoumbi 2004: 638). ${ }^{8}$ Compounds are used to refer to this type of oil palm in the Angolan Kongo (H16) variant, in which Gossweiler (1953: 512) noted diba malau, 'var. virescens dura' and diba matundaba, 'var. virescens tenera'. The previously mentioned Ntandu (H16g) compounds, in which $b a$ is modified by different names for the palm nut, possibly distinguish different kinds of oil palms according to their nut type. However, the available data do not permit us to corroborate this hypothesis. ${ }^{10}$ Other bá compounds in Ntandu (H16g) differentiate oil palms with regard to age: bá dinteende (or ntééndé ba), 'jeune palmier'; bá díyúmbu, 'vieux palmier, très élancé' (Daeleman \& Pauwels 1983: 208). As discussed in more detail further on, ntééndé is the reflex of the common Bantu noun stem *-téndé.

As shown on Map 2, ${ }^{\circ}-b a ́$ reflexes occur predominantly in the central and southern parts of Western Bantu. They are found in Guthrie's zones B (50-80), C $(30+60-80), H(10+40)$, and R (R11). In historical terms, according to Vansina's classification (1995), based on the lexicostatistical data published later on in Bastin et al. (1999), the distribution of ${ }^{\circ}$-bá links the West Coastal languages (including B40-80 and $\mathrm{H}$, except for $\mathrm{H} 41$ ) with the central Forest Bantu languages of the Inner Congo Basin (C33-35, C50-C80, B82). ${ }^{11}$ The only languages that do not belong to one of these groups are Mbala (H41) and Umbundu (R11). Both are adjacent to the West Coastal group, but are thought to be part of the South-west group.

\footnotetext{
${ }^{8}$ Another specific noun stem for the virescens type recurs in the B10-B20 languages and in Fang (A75): -koma (Raponda-Walker \& Sillans 1961: 335-336). However, it cannot be considered local because it also occurs in zones $\mathrm{L}$ and $\mathrm{K}$ as the name of the oil palm or of other species of palm-tree. Interestingly, in Tetela (C71), dyeékómá means 'noix de palme (verte à maturité)' (Hagendorens 1975: 54).

${ }^{9}$ Cf. Swartenbroeckx (1973: 295, 499): malàfu, malàvu, 'vin de palme, malafou; spiritueux'; ntùndúbà, -dúwà, 'noix palm. vert-rouge, refusée par certains'.

${ }^{10}$ Cf. Swartenbroeckx (1973: 179, 416): kisámbu, 'régime palm., noix de palme fraiche'; ngási, 'noix palm. entière'.

${ }^{11}$ As I will comment more extensively further on, the C50 are the only languages of this subgroup, attesting *-bídà, rather than ${ }^{\circ}$-bá reflexes.
} 


\section{Map 2: $\quad$ The distribution of ${ }^{\circ}-b a ́$ inside the Bantu domain}

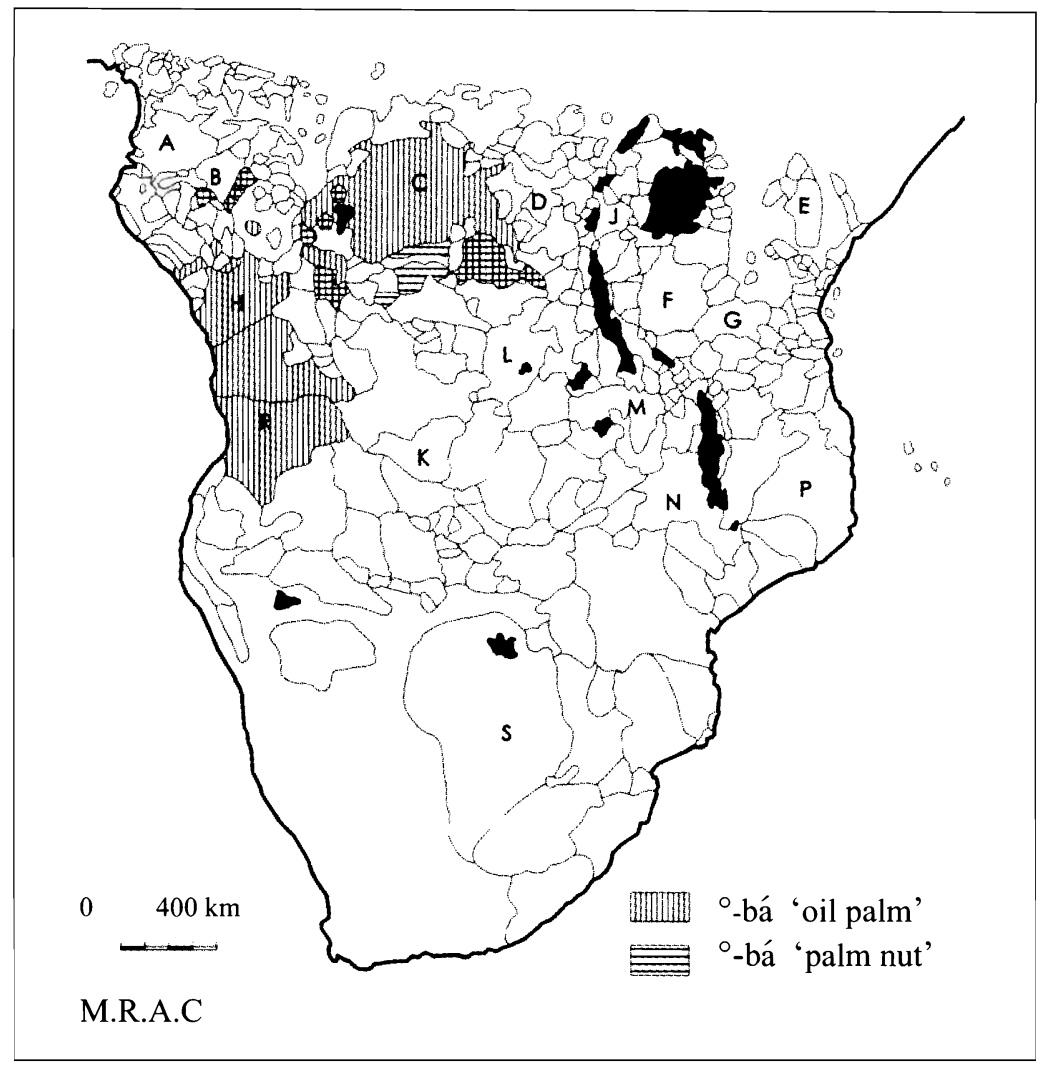

3.2 *-bídà, 'oil palm'. Table 2 lists reflexes of *-bídà, 'oil palm' from each Bantu zone in which it occurs.

Table 2: Reflexes of *-bídà, 'oil palm', 'palm nut'

A44 Nen ibúl cl. 7-8 'régime mûr de (Dugast 1967:77) noix de palme'
A85d Tsong oyila
cl. $7-8$
'E. var. nigrescens'
(Raponda-Walker \&
Sillans $1961: 335$ )
C101 Babole dibílà
cl. 5-6 'palmier à l'huile'
(Leitch $1991: 8$ )
D25 Lega kibíla
cl. 7-8 'palm tree or nut'
(Botne 1994: 116)

The supplementary data which I collected do not contradict the phonological reconstruction of *-bídà, as proposed by Guthrie (1967-1971). The only problem 
may consist in the identification of certain reflexes. Due to consonant attrition, a present-day *-bídà reflex may be difficult to distinguish from a ${ }^{\circ}-b a ́$ reflex. The Mbonge (A121) term lí-já/mí-já, 'oil palm' (Williamson 1973: 58), for example, could be interpreted as a reflex of '-bá. Nevertheless, data from closely related languages like Londo (A11) and Kundu (A11c), where scholars have documented -íà (díà/míà), 'palm tree' (Kuperus 1985: 261) and díà/míà, 'ausgewachsene und gereinigte Ölpalme' (Ittmann 1971: 159) respectively, suggest that the Mbonge term is a *bídà reflex. Between two vowels, *d becomes $\varnothing$ in these languages, which may lead to the semivocalisation of $i$.

Morphologically, the reflexes of *-bídà may vary in noun class. As is the case for ${ }^{\circ}-b a ́$ reflexes, noun class alternation is a common device for semantic variation between the different parts of the tree. In Nen (A44), for instance, nibil (cl. 5) is the name of the tree, while ùmíl (cl. 3) signifies 'noix de palme' and ibíl 'regime mûr de noix de palme' (Dugast 1967: 77, 141, 192). Nevertheless, this morphosemantic subdivision is slightly less systematic than for ${ }^{\circ}-b a ́$. In most languages, the name of the tree itself also occurs in cl. 5-6, e.g. Nen (A44) nibíl (Dugast 1967: 141); Enyele (C10) ebíya (Caroline Dedisa pers. comm.); Ngombe (C41) libía (Rood 1958: 256). In the Myene (B10) languages, on the other hand, the noun for the tree belongs to cl. 14, taking its plural in cl. 6, e.g. Orungu (B11b) oyílálambílá (Odette Ambourouè pers. comm.). In other languages, a cl. 9-10 noun is attested, e.g. Kombe (A33b) mbía (Fernandez 1951: 412), Binza (C30) mbíla (Motingea 1996: 259), Bua (C44) mbia (De Cort et al. 1912: 23). Both unique, Lega (D25) uses a cl. 7-8 reflex to refer to both the tree and its nut (see table 2), while Bubi (A31) attests öbiilá, a cl. 3-4 noun (Bolekia Boleká 1991: 159).

With respect to the fruit of the oil palm, the most common class pairings are also cl. 9-10 and cl. 11-10, e.g. Baakpe (A22) mbía/mbía (cl. 9-10) (Kagaya 1992: 112), Tsong (B85b) ńdzyá/ńdzyá (cl. 9-10) (Iliku Mimpiya Dibata 1979: 111), Lingala (C36d) lobíla/mbíla (cl. 11-10) (Kawata 2003: 137), Lyombo (C53) lo-íla/mi-bíla (cl. 11-10) (Stoop 1977: 32). Reflexes of *-bídà belonging to noun classes other than 9-10 or 11-10 with the meaning 'palm nut' have only been noted in Nen (A44) and Enyele (C10), respectively ùmíl (3-4) (Dugast 1967: 192) and mumbíya/mambíya (3-6) (Caroline Dedisa pers. comm.). ${ }^{12}$

\footnotetext{
${ }^{12}$ Synchronically, the stem of the Enyele ( $\left.\mathrm{C} 10\right)$ noun clearly is -mbiya. Diachronically, however, this stem should be analysed as m-biya, the cl. $9(/ 10)$ noun prefix having been subsequently integrated into it.
} 
In a restricted number of languages, such as Baakpe (A22), Nen (A44), Orungu $(\mathrm{B} 1 \mathrm{lb})$, and Bobangi $(\mathrm{C} 32)$, the *-bidà reflex also refers to the bunch of oil palm nuts. Interestingly, in this case, the noun stem always occurs in cl. 7-8, e.g. Orungu (B11b) ezílályílá (Odette Ambourouè pers. comm.). Just as for ${ }^{\circ}$-bá, the reflexes referring to the nut (or the bunch of nuts) generally co-exist, language internally, with a reflex designating the tree itself, but this is not necessarily true the other way around. It is only in Duala (A24) and some C50 languages that the *-bídà reflex is uniquely used for designating the palm nut, not the oil palm. In Duala (A24), a reflex of another common Bantu noun stem for the oil palm, i.e. *-téndé, is attested. The C50 languages attest the local noun stem -tòkò, discussed in footnote 6 . In Kele (C55), both nouns are combined into the following compound: litoko lia mbila, 'le palmier' (Anon n.d.). Although the uneven nature of documentation may somehow lead to an underestimation of the actual number of reflexes referring to the palm fruit, the tree seems to constitute the semantic focus of *-bidà, while 'palm nut' and 'bunch of palm nuts' seem to be semantic derivations by noun class variation.

Concerning the semantics of $*$-bidà, except for the morphosemantic derivations just treated, it is quite obvious, from the available comparative data, that this noun generally refers to the Elaeis guineensis Jacq. The only language in which it unmistakably concerns another type of palm tree is Bubi (A31): öbiilá, 'palmera datilera' (Bolekia Boleká 1991: 159). However, in some languages, the translation does not allow one to assess whether it specifically refers to the oil palm or serves as a generic name for palm trees, e.g. Mobenge (C43) bira, 'palmier' (Bareau \& Reding 1912: 116). Botanical details with respect to the different varieties of oil palms are, once again, mainly found in the work of Raponda-Walker \& Sillans (1961). In several of the Gabonese Bantu languages which they cover (A34, B11a-e, B21-22), the simple *-bídà reflex always refers to the nigrescens variety, while compounds are used to refer to other varieties or sub-varieties, e.g. Benga (A34) mbiya, 'E. var. nigrescens', mbiya-nkóma, 'E. var. virescens', and mbiya-ibóbu 'E. sub. var. tenera' (Raponda-Walker \& Sillans 1961: $335-6)^{13}$

With respect to the geographic range, the reflexes of *-bidà occur in Guthrie's zones A-(10-40), B (10-20), C (10+30-50) and D (D25) (cf. Map 3). In other words, their distribution is widespread but quite scattered within Forest Bantu.

\footnotetext{
${ }^{13}$ Note that the determinant nkoma of the first compound corresponds to the recurrent noun stem -koma referring to the virescens variety in the B10-B20 languages and in Fang (A75). The precise meaning of $i b o ́ b u$ could not be retraced.
} 
Interestingly, they are found in perfect complementary distribution with the ${ }^{\circ}-b a$ ' reflexes. These noun stems are never encountered together in the same language, although they may exist separately in neighbouring languages.

\section{Map 3: The distribution of *-bídà inside the Bantu domain}

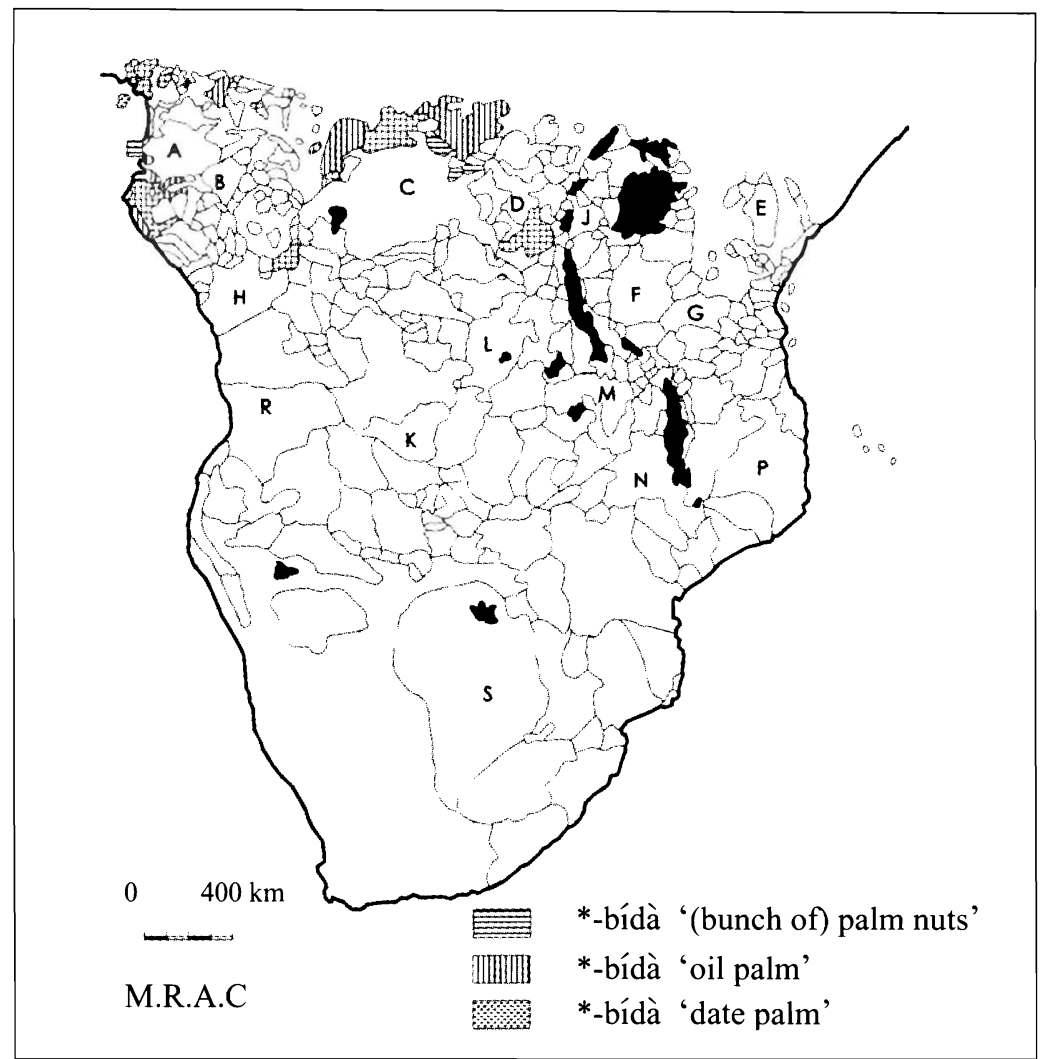

Consider, for example, Guthrie's C30 languages. As described above, Ntomba (C35a) and Bolia (C35b), two southern members of the C30 group, attest -bá. In constrast, the more northerly C30 languages, such as the Ngiri languages spoken between the Ubangi and Congo rivers and Bobangi (C32) generally attest *-bída (Motingea 1996: 259; Whitehead 1899: 407). ${ }^{14}$ Still more intriguing is the fact that this subgroup seems to correspond to a genetic split. In several classifi-

${ }^{14}$ Among the Ngiri languages, Bomboma is the only to have another term, i.e. bo-langa (Motingea 1996: 259). 
cations (Bastin et al. 1983, 1999; Vansina 1995), Guthrie's C30 group falls apart in two distinct subgroups, splitting the C33-35 languages from the rest. The C3335 languages are, in general, more similar lexically to the C60-80 languages, with

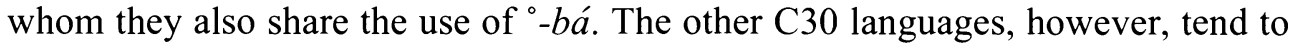
be lexically closer to the rest of zone C, notably to C40 and certain C10-20 languages. As mentioned before, Vansina (1995) groups the C33-35 and C60-80 languages with the $\mathrm{C} 50$ languages and Boma (B82) in a unit which he designated "Inner Basin." The rest of $\mathrm{C} 30$ would be made up of Ngombe (C41) and Bwela (C42), and possibly with Ngondi (C11) and Pande (C12), a unit he labelled "Rivers." "Inner Basin" and "Rivers" would constitute co-ordinate branches of the node he called "North Zaire." Several of these languages attest*-bídà.

The C10 languages attesting *-bídà are Aka (C104), Leke (C14) and Babole $(\mathrm{C} 101)$, whose positions in the classifications presented by Bastin et al. (1999) fluctuate according to the statistical procedure applied. The C40 languages (apart from Ngombe (C41)), in which *-bídà was found include Mobenge (C43) and Bua (C44). These languages are often set apart with certain D20-30 languages in a unit termed "Boan," which is believed to be one of the primary Bantu offshoots (Vansina 1995). Even if ${ }^{\circ}$-bá and *-bídà cannot be considered shared innovations diagnostic for genetic sub-grouping, their geographic distribution among Guthrie's zone C appears to be historically significant because their distribution tends to coincide with certain genealogical sub-divisions. However, the C50 languages, predominantly spoken along the upper Congo between Bumba and Kisangani and the very lowest end of the Lomami, deviate from this pattern. They attest *-bidà, but are lexicostatistically closer to the C33-35 and C60-80 languages than the rest of the zone $\mathrm{C}$ languages. ${ }^{15}$ Nevertheless, the historical background of this small language group is quite opaque. Based as they are on short lists of basic vocabulary, lexicostatistical classifications can only partially reflect linguistic history.

Quite relevant in this respect is the observation that the C50 languages also join the Congo River C30 and C40 languages, as opposed to the Inner Congo Ba-

${ }^{15}$ Although the $\mathrm{C} 50$ languages went with the $\mathrm{C} 40$ and Ngiri C30 languages in the Bastin et al. (1983) classification, they are set apart from them in the Bastin et al. (1999) classification, which was founded on far more extensive data and is, therefore, more reliable statistically. In most of the trees presented in this study, the C50 languages are lumped together as a coordinate branch of a cluster grouping C33-35, C60-80 and certain B80 languages, and as a primary offshoot of the node being at the same genealogical depth of the node uniting most of the other zone $\mathrm{C}$ languages. 
sin C33-35 and C60-80 languages, for at least one other field of cultural vocabulary, i.e. pottery terminology. As I have recently demonstrated (Bostoen 2005, 2006), they share at least two lexical innovations designating two different types of clay pots with the Congo River languages, while the Inner Congo Basin languages are characterised by a distinct set of parallel lexical innovations. Evidence for close relatedness with one language group based on fundamental vocabulary, but with another language group with respect to certain domains of cultural terminology, suggests the superposition of different lexical layers as a result of language shift(s), leaving substrate vocabulary in the superimposed language(s). Motingea (2004) has described the present-day sociolinguistic situation of the Inner Congo Basin as a unity within diversity, stemming from the unachieved linguistic absorption of the oldest small-scale Bantu-speaking communities by larger and socio-politically dominant settler communities. Apart from the Bobangi (C32) slave traders, the Mongo (C61) and Ngombe (C41) can be considered as the major immigrant groups. It was mainly the latter two groups who settled along the Upper Congo River, which could explain certain particular lexical similarities between these Congo River languages and the more eastern C50 languages spoken along this same aquatic highway.

The rest of the distribution of *-bídà reflexes provides additional historical information. Apart from Lega (D25), which is somewhat isolated, this noun stem occurs in the languages of zones $\mathrm{A}$ and $\mathrm{B}$, which, lexicostatistically, form a primary Bantu branch labelled 'North-west' by Vansina (1995). In other words, *-bídà is attested in two of the main Bantu subgroups, i.e. "North-west" and "West".

Interestingly, a reflex of *-bídà has also been noted in two Ubangian languages: in Monzombo (spoken in the border region between the Central-African Republic, the Democratic Republic of Congo and the Congo Republic), and in Bangando (spoken in the extreme south of Cameroon). They attest mbiá, 'palmier à huile' (Motte 1980: 128) and mbià, 'Palmée Elaeïs guineensis Jacq.' (Moñino 1995: 643) respectively. Having emigrated from the Ubangi River bend area in the extreme north-western part of present-day RDC, the Bangando community is known to have spoken a Bantu language before they underwent their 'Gbayaisation'. This language was the forerunner or at least closely related to the forerunner of the present-day Ngombe (C41) language (Moñino 1995, pers. comm.). In this respect, their *-bídà reflex could be seen as a retention from this period, rather than as a loan word from adjacent Bantu languages.

Other Ubangian languages of this region, however, attest a -banga like form for 'oil palm' (Moñino 1995: 643). This could be a Bantu loan, since a 
similar form is not only attested in neighbouring A80-90 languages, e.g. Mpiemo (A86c) baya, 'Elaeis guineensis Jacq. (Arecacae)' (Thornell 2004: 74), Kako (A93) báná, 'palmier à huile' (Ernst 1989: 79), but also occurs in more distant Bantu languages, referring to the palm kernel, e.g. Duala (A24) m'bangá ma mbía, 'le palmiste' (Helmlinger 1972: 276). ${ }^{16}$ With respect to the other Ubangian reflex, the Monzombo are not known to be former Bantu speakers. Hence, mbiá probably is a loan word from the Bantu language spoken by the Aka pygmies, with whom they exploit the Mongoumba region's fauna and flora. Although Motte (1980: 128) does not mention a *-bídà reflex as name for the oil palm in Aka (C104), di.bílà/mà.bílà, 'régime de noix de palmes; palmier à huile', and è.bílà/bè.bílà, 'régime de noix de palme' are mentioned by Thomas et al. (1993: 48). Maniacky (2005) recently identified other terms in the Monzombo food crop vocabulary that are probably Bantu in origin, namely words for three different yam species.

3.3 *-gàdı́, 'oil palm'/'palm nut'/'palm oil'. Table 3 shows some reflexes of the noun stem *-gàdí. Each Bantu zone in which it figures with a meaning related to the oil palm is represented. ${ }^{17}$ The reflexes which I collected confirm the phonological shape of the reconstruction *-gàdi, as proposed by Guthrie (19671971) and Bastin et al. (2003), on both the segmental and supra-segmental level. Guthrie (1967-1971) actually reconstructed *-yàdí, (C.S. 1898) and *-gàdí, (ps 202), both meaning 'oil'. In his comment on C.S. 1898, he raises the question whether it shares a common origin with *-gàd ĺ, 'oil palm' (C.S. 767), in spite of the divergence of shape and meaning. He concludes that the lack of evidence of associated nominals in any language with identical stems referring respectively to 'oil palm' and 'palm-oil' rules out treating them as osculant. In my view, there can be no doubt about the common origin of these nouns and they do co-occur in certain languages. Conversely, the necessity of reconstructing an alternative form having $* y$ as $\mathrm{C}_{1}$ is questionable. For one thing, several reflexes that Guthrie lists under the starred form *-yàdí, such as in Lwena (K14), Luyana (K31), Nkoya (L62), Kwanyama (R21), and Herero (R31), may be derived from *-gàdı́, since

${ }^{16}$ Crabb (1965: 83) lists several Ekoid languages attesting a -banga-like form for 'palm kernel', e.g. Abanyom ḿ-băy, which suggests that it could be considered for reconstruction to PB.

${ }^{17}$ In zones D, F, and M, the above-cited reflexes are the sole attestations of *-gàdí. These forms should not be taken as indications for the term's spread among zones D, F, and M languages. As I will explain further on, it is possible that certain of these easternmost reflexes spread through lexical diffusion. 
* $g$ regularly becomes $\varnothing$ in these languages. However, it is true that such is not the case in the zone $\mathrm{B}, \mathrm{C}$, and $\mathrm{H}$ languages he cites. ${ }^{*} g$ regularly becomes $k$ in these languages. However, as I have previously argued for the osculant pair *-bigá '-bijá, 'pot' (Bostoen 2004, 2005), this does not necessarily imply a distinct origin. The existence of forms such as agali in Mpongwe (B11a) or omagadhi in Ndonga (R22), favours $* g$ as $\mathrm{C}_{1}$.

\section{Table 3: Reflexes of *-gàdí, 'oil palm'/'palm nut'/'(palm) oil}

$\begin{array}{llllll}\text { B302 } & \text { Simba } & \text { gékadi } & \text { cl. 7-8 } & \begin{array}{l}\text { 'E. var. } \\ \text { nigrescens' }\end{array} & \begin{array}{l}\text { (Raponda-Walker \& } \\ \text { Sillans 1961: 335) }\end{array} \\ \text { C81 } & \text { Ndengese } & \text { bongaji } & \text { cl. 14 } & \text { 'palmpit' } & \text { (Goemaere nd.: 40) } \\ \text { D25 } & \text { Lega } & \text { kikasí } & \text { cl. 7-8 } & \begin{array}{l}\text { 'palm tree or } \\ \text { nut used for oil' }\end{array} & \text { (Botne 1994: 65) }\end{array}$

F11 Tongwe sigasi cl. 7-8 'palm tree (Kakeya \& Nishida (oil palm)' 1976: 49)

H16g Ntandu maási cl. 6 'huile de (Daeleman \& palme' Pauwels 1983: 208)

J66 Ha umugázi cl. 3-4 'oil palm' (Nakagawa 1992: 25)

K14 Lwena ngáji cl. 9-10 'nut of the (Horton 1953:214) oil palm'

L23 Songye kyàjí cl. 7-8 'régime de (Stappers 1984: 74) noix de palme'

M14 Rungu chazi cl.7-8 'oil palm' (Nurse \& Philippson 1975)

With respect to phonological correspondences, I would also like to draw attention to a series of terms that resemble the regular *-gàdi reflexes, both formally and semantically. There are a series of nouns similar to the Swahili (G42) terms mnazi (cl. 3-4) 'coco-nut tree', and nazi (cl. 9-10), 'a coco-nut' (Johnson 1950: 292) that generally refer to the Cocos nucifera Linn., e.g. Nyakyusa (M31) unnasí (cl. 9-10), 'coconut palm' (Felberg 1996: 153); Yao (P21) naási (cl. 9-10), 'coco, palmeira' (Viana 1961: 153). In certain languages, however, they seem to refer to the oil palm. In the Tanzania Language Survey (Nurse \& Philippson 1975), the Samialugwe (E34) noun omunazi (cl. 3-4), the Sango (G61) noun mnasi (cl. 3-4) and the Luhya (J31) noun munazi (cl. 3-4) are mentioned as equivalents of the Swahili (G42) noun mchikichi (cl. 3-4), 'oil palm', while the 
Tooro (J13) noun omunazi is given as the translation of the Swahili (G42) noun mtende (cl. 3-4), 'date palm'. All these terms share a noun stem beginning with $/ \mathrm{n} /$, which cannot be considered as the regular reflex of $* g$, certainly not in postnasal position, where it is normally conserved. Further research should determine whether these forms can be linked to regular reflexes of *-gàdí.

Cross-linguistically, the reflexes of ${ }^{*}$-gàdi figure in a number of different noun classes. Once again, noun class variation induces semantic change. Excluding certain rare exceptions, such as Nande (J42) engasi (cl. 9-10), 'oil palm tree, nut palm' (Fraas n.d.: 276, 279) or Ha (J66) umugázi (cl. 3-4), 'oil palm' (Nakagawa 1992: 25), nouns referring to the tree itself generally occur either in cl. 5-6 or in cl. 7-8, e.g. Kerewe (J24) igazi (cl. 5-6), 'oil palm' (Nurse \& Philippson 1975), Tongwe (F11) sigasi (cl. 7-8), 'palm tree (oil palm)' (Kakeya \& Nishida 1976: 49). In three L20-30 languages, however, cl. 7-8 reflexes designate the bunch of oil palm nuts, e.g. Hemba (L34) kyàzi, 'le régime du palmier élaïs' (Vandermeiren 1913: 829). In Ha (J66), the cl. 5-6 reflex igázi refers to the nut of the oil palm (Nakagawa 1992: 25).

The most widespread class pairings regarding the fruit of the oil palm are once more cl. 9-10 and cl. 11-10, e.g. Lwena (K14) ngáji/jingáji (cl. 9-10), 'nut of the oil palm' (Horton 1953: 214), Sanga (L35) lwaji/ngaji (cl. 11-10), 'noix du palmier à huile' (Coupez 1976: 19). ${ }^{18}$ In this capacity, the reflex may be used as a modifier in connective constructions whose head noun is the name for '(palm) tree' or 'nut', e.g. Kimbundu (H21) muxi ua ngaji, 'palmeira' (Da Silva 1994: 460), Kiluba (L33) mani a ngazi, 'noix de palme' (Gillis 1981: 344), Shi (J53) mavurhä gëengäzi, 'huile de noix de palme' (Cuypers 1970: 48) or the aforementioned Ntandu (H16g) compound bá dingási (Daeleman \& Pauwels 1983: 207).

Unlike ${ }^{\circ}$-bá and *-bídà, *-gàdí does not seem to refer primarily to the tree. It is only in a minority of languages, notably just to the east of the rainforest, that its reflexes exclusively designate the oil palm tree. In several western languages, this term only occurs with the meaning 'palm nut', while another noun is used for the tree, e.g. Pove (B22c) śbs, 'palmier Elaeis var. nigrescens Jacq.', ngadí, 'noix

${ }^{18}$ In Ciluba (L31a), the nasal prefix of the cl. 10 plural form has been integrated in the noun stem: lungaji/ngaji, 'une noix de palme' (De Clercq \& Willems 1960: 149). A similar integration of the cl. 9-10 noun prefix is observed in other languages and may suggest the derived status of these nouns, e.g. in Lwena (K14) mungaji/mingaji (cl. 3-4), 'nut-palm (oil palm)' (Horton 1953: 214), in the Congolese Ngwana variant of Swahili (G42) mngasi (cl. 3-4), 'palmier à huile (Elais guineensis)' (Sacleux 1941: 534) or in Ndengese (C81) bongaji (cl. 14), 'palmpit' (Goemaere, n.d.: 40). 
de palme' (Mickala Manfoumbi 2004: 638). This could suggest that 'palm nut' is a more primary meaning than 'oil palm' and that the latter is the result of a metonymically motivated shift or the syncope of periphrases, such as in Ntandu (H16g) and Kimbundu (H21), of which the first element, meaning '(palm) tree', has been dropped. Moreover, *-gàdı may also designate the oil extracted from the palm nut. When this is the case, the noun stem is always preceded by the prefix of cl. 6, e.g. Ntandu (H16g) máasi 'huile de palme' (Daeleman \& Pauwels 1983: 207). In Mpongwe (B11a), agali m'imbila refers to the palm oil, while agali $m$ 'anyanga designates the palm kernel oil. ${ }^{19}$ Unsurprisingly, the modifying nouns signify 'palm nut' and 'palm pit' respectively. In Kimbundu (H41), the cl. 6 reflex apparently needs a determinant meaning 'oil palm' in order to refer specifically to the palm oil: maji ma ndende (Da Silva 1994: 67).

These findings correspond to what we observe in certain Western Bantu languages of zones $\mathrm{K}$ and $\mathrm{R}$, where the ${ }^{*}$-gàdı reflexes in cl. 6 seem to have undergone semantic broadening. These reflexes refer to any (vegetable) oil or fatty substance, e.g. Mbukushu (K333) maghadhi, 'oil, greasy liquid, able to burn' (Wynne n.d.: 364), Kwanyama (R21) omaadi, 'vegetable oil, animal fat, adipose tissue, mineral grease; ointment' (Turvey et al. 1977: 85). However, contrary to Vansina (2004: 44), there is no causal connection between this semantic shift and the fact that these languages are spoken south of the extreme limits where the tree could grow. This semantic generalisation is also observed in languages spoken inside the oil palm belt, e.g. Ndumu (B63) mari, 'toute sorte de matière grasse; huile; beurre; graisse' (Biton 1907: 62), Yans (B85) meay, 'huile, graisse' (Nguma 1986: 133), Bobangi (C32) māli, 'palm oil/fat, grease, oil' (Whitehead 1899: 407). ${ }^{20}$

${ }^{19}$ Remarkably, Connell (1998) reconstructed to Proto-Lower-Cross a similar form for "palm kernel oil', i.e. *ì-mànyàyà. In spite of this striking resemblance, more data and research are needed to decide whether this form really is a cognate to the term a-nyanga for 'palm kernel' attested in Mpongwe (B1la) and some other Gabonese languages as Mbede (B61) and Ndumu (B63). The stem of these Bantu forms is nyanga or maybe -anga, ny being a cl. 9 noun prefix. These forms could be related to the -banga term observed in several northwestern Bantu language for 'palm kernel' (cf. infra).

${ }^{20}$ In each of these languages, the cl.6*-gàdí reflex is modified by a noun meaning 'palm nut' or 'palm kernel' in order to designate the palm oil: Ndumu (B63) mari ma mbă, 'huile de palme', mari ma anânga, 'huile faite avec l'amande des noix de palme'; Yans (B85) meay a mba, 'huile de palme'; Bobangi (C32) māli ma ndìka 'oil from kernels', māli ma mibōkū 'oil from nuts of oil palm'. 
In the same respect, it is intriguing to observe that an identical noun stem, often belonging to cl. 6, occurs in the Eastern Bantu languages of zones E, F, G, N, M, P, and S with the meaning 'blood', e.g. Chewa (N31b) magazi, (Paas 2004: 243), Makonde (P23) myadi, (Guerreiro 1963: 114), Sotho-N (S32) madi (Ziervogel \& Mokgokong 1975: 146). Despite their complementary geographical distribution, Guthrie (1967-1971) did not suggest a historical link between *-gàdí,

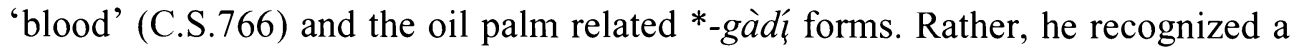
common origin with *-gìdá, 'blood' (C.S. 824) through metathesis of the vowels, but the historical link between these etymons is rather unlikely. The only common ground between both might be the fact that *-gàdí replaced *-gìdá for reasons of taboo (Bastin 1997: 20). Nevertheless, a metaphorically induced semantic shift from palm oil, usually reddish in colour, to 'blood' seems highly probable (Bastin 1997: 20). If this hypothesis bears out, it is all the more likely that the basic meaning of *-gàd' was 'palm oil' and/or 'palm nut', rather than 'oil palm'. According to the available data, Rungu (M14) is the only language where two *-gàdi reflexes uniting both semantic fields co-exist, i.e. chazi (cl.7), 'oil palm' (Nurse \& Philippson 1975) and úwazi (cl. 14), 'blood' (Kagaya 1987: 59). Kagaya (1987) does not mention a word for 'oil palm' but Lee Bickmore (pers. comm.) confirms the coexistence of both meanings. He notes uwaazi for 'blood', umuti waa ngazi (in short, umwaangazi) for 'palm tree' and amafuta yaa ngazi or amafuta yaa mwangazi for 'palm oil'. Given that the meaning 'blood' only occurs in eastern Bantu languages, it is likely that this shift results from a semantic innovation going back to their latest common ancestor.

The precise tree variety referred to by reflexes signifying 'oil palm' is only known for the Gabonese languages of the Raponda-Walker \& Sillans (1961: 335) survey. In Simba (A302), Apindji (A304) and Tsogo (B31), gékadi designates the most common nigrescens variety. In Kongo (H16) mazi ma mona refers to the oil extracted from the nut of the albescens variety (Gossweiler 1953: 513). No further botanical details for $*_{-}$gàd $ı$ are known. In some languages spoken at the southern border or just outside the equatorial rainforest, however, * ${ }^{*}$ gàdı reflexes refer to another kind of palm tree, e.g. Tetela (C71) dikadí, 'Raph. Laurentii de $W$. gros raphia des marais dont les rachis servent aux constructions' (Hagendorens 1975: 35), Bushong (C83) ikady, 'palmier de rivière' (Vansina 1959: 97), Ciluba (L31a) dikadi, 'le palmier bambou des marais' (De Clercq \& Willems 
1960: 54). ${ }^{21}$ In Rwanda (J61), to the east of the rainforest, ingazí is said to refer to the Senegal date palm (Phoenix reclinata Jacq.) (Jacob 1984: 342).

\section{Map 4: The distribution of *-gàdı inside the Bantu domain}

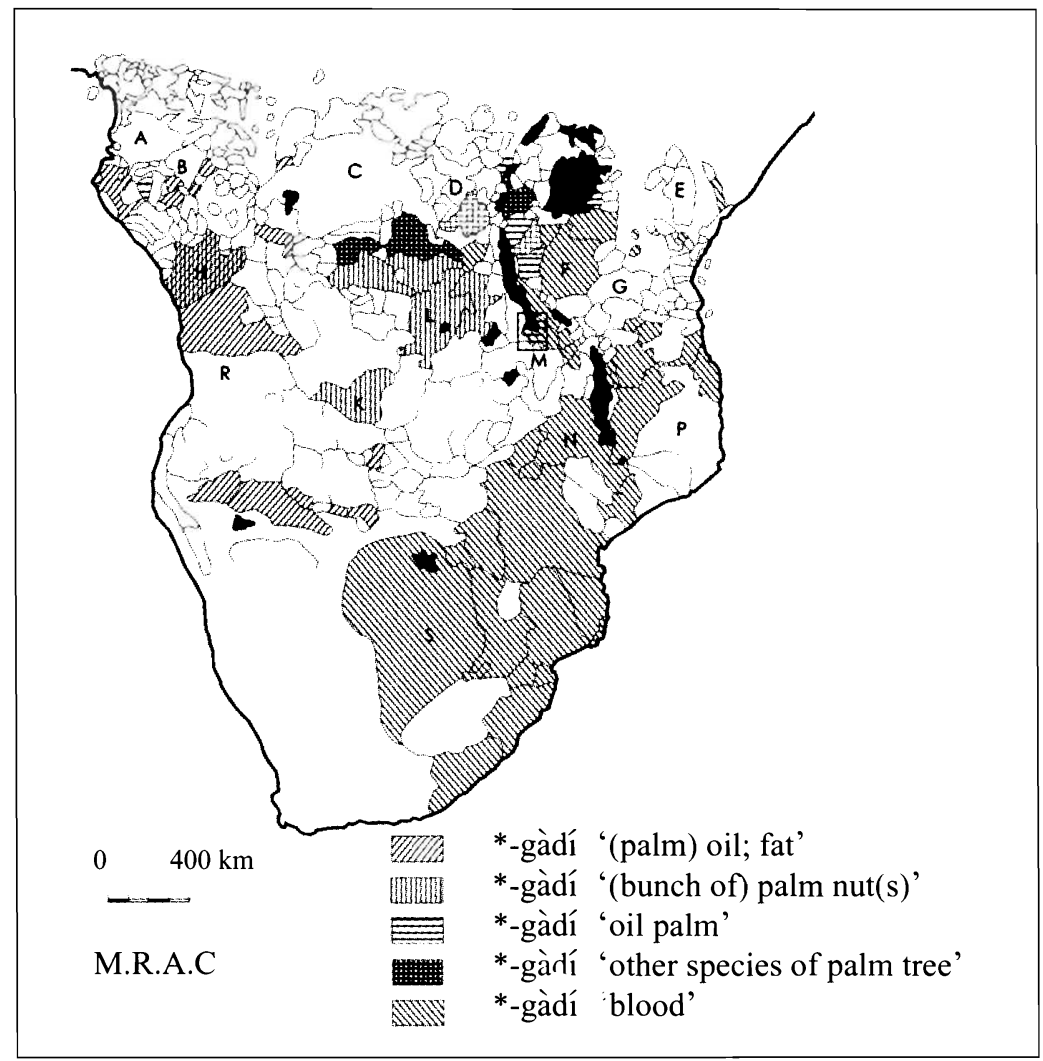

Reflexes of *-gàdí whose meaning relates to oil palm occur in the following languages or language groups: B10 ('palm oil'), B30 ('oil palm'), Ndengese (C81) ('palm nut'), Lega (D25) ('oil palm' + 'palm nut'), Tongwe (F11) ('oil palm'), Kongo (H16) ('oil palm' + 'palm oil'), Kerewe (J24) ('oil palm'), J40-60

${ }^{21}$ Since $* g$ regularly gives $\varnothing$ in intervocalic position in Ciluba (L31a), this form cannot be a regular reflex of *-gàdí. It probably is a loan word copied from one of its northern neighbours, such as Tetela $(\mathrm{C} 71)$ or Bushong $(\mathrm{C} 83)$, where ${ }^{*} g$ regularly becomes $k$. Given that $d i$ kadi attests the reversed tone pattern typical of Ciluba (L31a), it might be a relatively old loan. 
('oil palm' + 'palm nut'), Lwena (K14) ('oil palm' + 'palm nut'), L20-30 ('(bunch of) palm nut(s)'), Rungu (M14) ('oil palm'). If one takes into account the reflexes having undergone a semantic generalisation to 'oil' or 'fat', the B5080, K30 and R20 languages and Bobangi (C32) can be included as well. In other words, *-gàdí manifests a quite scattered distribution, which is predominantly central and southern West Bantu. It has an extension, however, to some of the most western East Bantu languages spoken on both sides of Lake Kivu and Lake Tanganyika, where it predominantly functions as the name of the oil palm itself. It is possible that some of these easternmost languages obtained their reflex through lexical diffusion. As I noted above, the Lega (D25), Tongwe (F11), and Rungu (M14) reflexes are the sole documented attestations of *-gàdí, 'oil palm' in their respective zones.

These languages being situated in the vicinity of Lakes Tanganyika and Kivu, precolonial regional trading networks interconnecting the Great Lakes and the Lake Corridor regions may have played a role in their diffusion. Very telling in this respect is the testimony of H.M. Stanley (1872) on the regional and longdistance trade at Ujiji market (my italics):

There were the agricultural and pastoral Wajiji, with their flocks and herds; there were the fishermen from Ukaranga and Kaole, from beyond Bangwe, and even from Urundi, with their whitebait, which they called dogara, the silurus, the perch, and other fish; there were the palm-oil merchants, principally from Ujiji and Urundi, with great five-gallon pots full of reddish oil, of the consistency of butter; there were the salt merchants from the salt-plains of Uvinza and Uhha; there were the ivory merchants from Uvira and Usowa; there were the canoe-makers from Ugoma and Urundi; there were the cheap-Jack pedlers from Zanzibar, selling flimsy prints, and brokers exchanging blue mutunda beads for sami-sami, and sungomazzi, and sofi (...) Here were found Waguhha, Wamanyuema, Wagoma, Wavira, Wasige, Warundi, Wajiji, Waha, Wavinza, Wasowa, Wangwana, Wakawendi, Arabs, and Wasawahili, engaged in noisy chaffer and barter. [p. 473]

This could explain how the term trickled down from zone $\mathrm{J}$ for instance, where it is attested in $\mathrm{J} 20 / 40 / 50 / 60$ languages, into some more southerly languages, such as Tongwe (F11) and Rungu (M14). Yet, even if some of the easternmost *-gàdí reflexes for 'oil palm' can be played down as lexical borrowings, the noun is attested in East Bantu. Moreover, if one also integrates the reflexes meaning 'blood', hypothesizing that they stem from the same etymon but have undergone a semantic shift, one definitely finds a general Bantu distribution. Consequently, 
* gàdí is a likely candidate for reconstruction in PB, not as name of the oil palm, but as a word for the fruit and its oil. ${ }^{22}$

3.4*-téndé, 'oil palm'. Table 4 presents present-day reflexes of the noun stem -téndé meaning 'oil palm' or having a related signification.

\section{Table 4: Reflexes of *-téndé, 'oil palm'/palm oil'}
A24 Duala léndé
cl. 5-6 'Eléide de
(Helmlinger
Guinée'
1972: 624)
B11b Orungu nténdé cl. 9-10 'oil palm'
(Odette Ambourouè

D14 Enya ceténdé
G42 Swahili mtende
cl. 7-8 'palmier' pers. comm.)
H16g Ntandu ntééndéba
cl. 3-4 'dattier'
(Kolni 1971: 89)

K13 Lwena ndende
cl. 9-10 'jeune
(Sacleux 1941: 610)
K13 Lwena ndende
cl. 9-10 'palm oil'
(Daeleman \&
R11 Umbundu ondende
cl. $9-10$
'azeite da palmeira; lente 1972: 459-60) óleo de palma'

The formal reconstruction of the noun *-téndé, as proposed by Guthrie (19671971), does not pose a problem in the light of the additional data which I have collected. As a result, it does not need to be reconsidered here.

Except for the Eastern Bantu *-téndé attestations belonging to cl. 3-4, which I will comment on later, the noun stem most often occurs in cl. 5-6 and cl. 9-10, and it generally refers to the tree itself, e.g. Noho (A32) ilende (cl. 5-6), 'Ölpalme' (Adams 1907: 72), Nkomi (B11e) ntèndè (cl. 9-10), 'E. var. nigrescens' (Raponda-Walker \& Sillans 1961: 335). Apart from the aforementioned Enya (D14) reflex in cl. 7-8, the Nen (A44) noun hèlende, belonging to cl. 19, is one of the rare exceptions to this trend. As the last two examples of table 4 show,

\footnotetext{
${ }^{22}$ An anonymous reviewer claimed that *-gàdí is cognate with Proto-Delta-Cross *-kód 'raphia palm' (Connell 1998) and that therefore the possibility of *-gàdí as PB 'raphia palm' should be considered. Indeed, some Bantu reflexes refer to this palm tree or to a related species, e.g. 'bamboo palm' in Dzing (B86) and Ntomba (C35a), but these seem to be local innovations, rather than retentions. More evidence is also needed to demonstrate that the PDC form really is a cognate.
} 
cl. 9-10 reflexes may also refer to the palm oil. However, the Lwena (K14) and Umbundu (R11) nouns are the only ones of their kind. ${ }^{23}$ Otherwise, unlike the three common Bantu nouns treated so far, *-téndé is never used to designate either palm oil or the palm nut. Its semantic scope seems to be limited to the tree as such.

In western Bantu, ${ }^{*}$-téndé refers almost without exception to the oil palm. ${ }^{24}$ It is only in Akoose (A15) that it is said to be the name of the Raphia spp.: atên (cl. 5-6), 'palm, raffia' (Hedinger \& Hedinger 1982: 42). In Umbundu (R11), undente (cl. 3-4) functions, just like the above-treated ${ }^{\circ}-b a$ reflex eva, as the generic name for different kinds of palm trees (Le Guennec \& Valente 1972: 460). ${ }^{25}$ As regards botanical specifications, inasmuch they are known, unmodified *-téndé reflexes seem to refer to the most common nigrescens variety. Such is the case in Fang (A75), Orungu (B1 1b) and Nkomi (B11e) (Raponda-Walker \& Sillans 1961: 335). In the former language, the compound alen-bingom, uniting the *-téndé reflex and the ${ }^{\circ}$-koma reflex mentioned above, designates the virescens variety. In Kimbundu (H21), (ndende ia) hôhô refers to the "var. macrosperma \& nigrescens forma dura' and ndende ia fumbe to the 'var. nigrescens forma pisifera' (Gossweiler 1953: 513). ${ }^{26}$ Interestingly, a recurrent connotation associated with *-téndé is not botanical in nature, but concerns the age of the palm tree. In several widely dispersed languages, such as Nen (A44), Punu (B43), Ntandu $(\mathrm{H} 16 \mathrm{~g})$, and Yaka $(\mathrm{H} 31)$, the *-téndé reflex is said to refer to a young oil palm. In

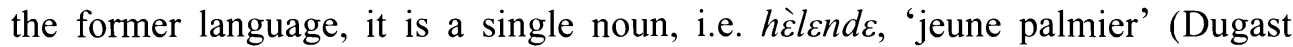
1967: 62). In the other languages, it is part of a compound. In Punu (B43) and Yaka (H31), similar terms have been observed, respectively diréndə dí mbari, 'petit palmier ayant déjà produit' (Blanchon 1994) and ntééndá mbáti, 'jeune palmier' (Ruttenberg 1969: 49). ${ }^{27}$ In Ntandu (H16g), it combines in different

${ }^{23}$ In Ngangela (K12b), a cl. 9 reflex modifies the word for 'tree' in order to refer to the oilpalm: múci wa ndéende (Maniacky 2003: 170). The word as such refers to the palm nut.

${ }^{24}$ Interestingly, in Brazil, the American Oil Palm (Corozo oleifera (HBK) Bailey) is called Dende do Para (Hartley 1967: 65).

${ }^{25}$ This noun is formally somewhat problematical, since ${ }^{*} n d$ in $\mathrm{C}_{2}$ position is in general directly reflected in Umbundu (see for instance the last example of table 4). I do not have a straightforward explanation for this irregularity.

${ }^{26}$ In Kongo-C (H16b), fümbe means 'larve de charançon du palmier (coléoptère)' (Laman 1936: 161).

${ }^{27}$ The nouns that modify the *-téndé reflex have been translated as 'palmier à huile' (Blanchon 1994 ) and 'palmier' respectively (Ruttenberg 1969: 140). Both nouns seem to be part of a lo- 
ways with the `-bá reflex: ntééndé ba, bá dinteende, 'jeune palmier' (Daeleman \& Pauwels 1983: 207). As I have mentioned before, the noun bá also combines with diyúmbu to refer to an old oil palm. The scattered repetition of this connotation of youth could indicate that it is quite old.

Remarkably, in a large number of languages, belonging to Guthrie's zones E (40-70), F (10-20), G (20-60), J (20+30+60), M (10-30), N (13), and P (10-20), *-téndé has a reflex meaning 'date palm' (Phoenix dactylifera Poir.). Some rare exceptions notwithstanding, such as Gikuyu (E51) ndende (cl.9-10), Kerewe (J24) itende (cl. 5-6), and Jita (J25) gintende (cl. 7n-8n) (Nurse \& Philippson 1975), all these nouns occur in cl. 3-4, e.g. Nyakyusa (M31) unteende/imiteende (Felberg 1996: 133). The dense distribution of the noun with this sense in Eastern Bantu languages is surprising, since the date palm does not really thrive in this part of the continent and its fruits are generally imported. In Eastern Africa, it is only planted as an ornamental, mainly on the coast and the offshore islands (Martin Walsh pers. comm.). The tree is subtropical in origin and cultivation. It has been introduced into some tropical countries, where it is usually completely sterile, as rain prevents pollination and the fruit will only ripen in a very dry climate. It mainly grows in a nearly rainless belt between 15 and $35 \mathrm{~N}$ Lat in the Sahara and the southern fringe of the Near East (Arabian Peninsula, southern Iraq, Jordan, etc., see Purseglove 1972).

The vast majority of this kind of *-téndé reflexes were found in the Tanzanian Language Survey database of Nurse \& Philippson (1975). These records might be an artefact of the way in which they elicited their data (i.e. asking informants to write down local language equivalents of Swahili terms). In Swahili (G42), mtende (cl. 3-4) refers to the date palm, tende (cl. 9-10) to its fruits. Being bilingual, it is possible that the informants just took the Swahili (G42) word for want of a appropriate term in their own language. Of course, it might also be that lots of languages have a borrowed term for this palm because of its appearance in translations of the Bible, hymns etc. (Martin Walsh pers. comm.). Since the Nurse \& Philippson (1975) data lack tonal notation, it is difficult to check whether these nouns have a tone pattern typical of recent loans, i.e. reflecting the Swahili (G42) penultimate accentuation instead of attesting regular tone correspondences characteristic of common Bantu inherited words. The few other pieces of data available, which stem from other sources, are rather uninformative with respect to reconstructing tone. In Jita (J25), for instance, where $i$ : n-té: nde, 'date (fruit)' was 
noted (Downing 1996: 233), the contrast *-cv́cv́/*-cv́cì is lost (Philippson 1998: 316). The resulting pattern is $-c \hat{v} c \hat{v}$, which is not distinctive from that of Swahili (G42) loans. Contrary to other Jita (J25) words, Downing (1996) does not consider it a Swahili (G42) loan. The Nyakyusa (M31) stress system is historically likewise unrevealing.

Whatever the case may be, even if the bulk of the *-téndé forms signifying 'date palm' are the result of a relatively recent diffusion from Swahili (G42), this still leaves open the question of how the date palm got to be called by this name. It looks most likely that *-téndé lost its original meaning 'oil palm' in favour of 'date palm', but where and when did this happen? One can assume that this semantic shift must have taken place along the East coast due to contact with the Arab world. This might have been in Swahili (G42), the language of ArabSwahili merchants, who laid the foundations of the lingua franca it is today. Its origin might also be pre-Swahili, in Proto-North-East-Coast Bantu for instance. However, due to the lack of relevant tonal data, the evidence for such a preSwahili origin is fairly weak. In Shambaa (G23), for instance, Yukawa (1984: 89) recorded ìténdé (cl. 3-4), 'date palm'. The tonal pattern of this noun could regularly correspond to *H-H, e.g. *-cimbá,'lion' > shímbá, `-pémbé 'horn' > mpémbé, '-kúndú 'anus'> ùkúndú, and it does not attest the tone pattern that is most common (but not exclusive) among Swahili (G42) loanwords, i.e. H-L. However, its tone pattern could also reflect *H-L, e.g. *-kúni, 'firewood' > ùkúní, *-kúndè, 'bean' > ìkúndé, which means that the tonal evidence is not conclusive on the possible pre-Swahili origin of the term. Whatever the origin of the term's semantic shift may be, it is remarkable that the date palm took the ancestral Bantu name for 'oil palm' upon its introduction to eastern Africa, and not that of a more closely related wild African relative, such as the Phoenix reclinata Jacq. ${ }^{28}$

Guthrie (1967-1971), having collected only five attestations, in both eastern and western Bantu languages, doubted whether C.S. 1712 consisted of direct cognates, since their meanings diverged. The supplementary reflexes we have collected permit us to confirm the unity of the comparative series concerned. As can be seen on Map 5, the geographic distribution of *-téndé consists of two continuous blocs of reflexes which differ semantically.

${ }^{28}$ The noun ${ }^{\circ}$-kindú is reported to be recurrent for the African wild date palm among the eastern Bantu languages of zones E, G, J, K, L, M, P, and S (Bastin et al. 2003, Guthrie 1967-71). 


\section{Map 5: The distribution of *-téndé inside the Bantu domain}

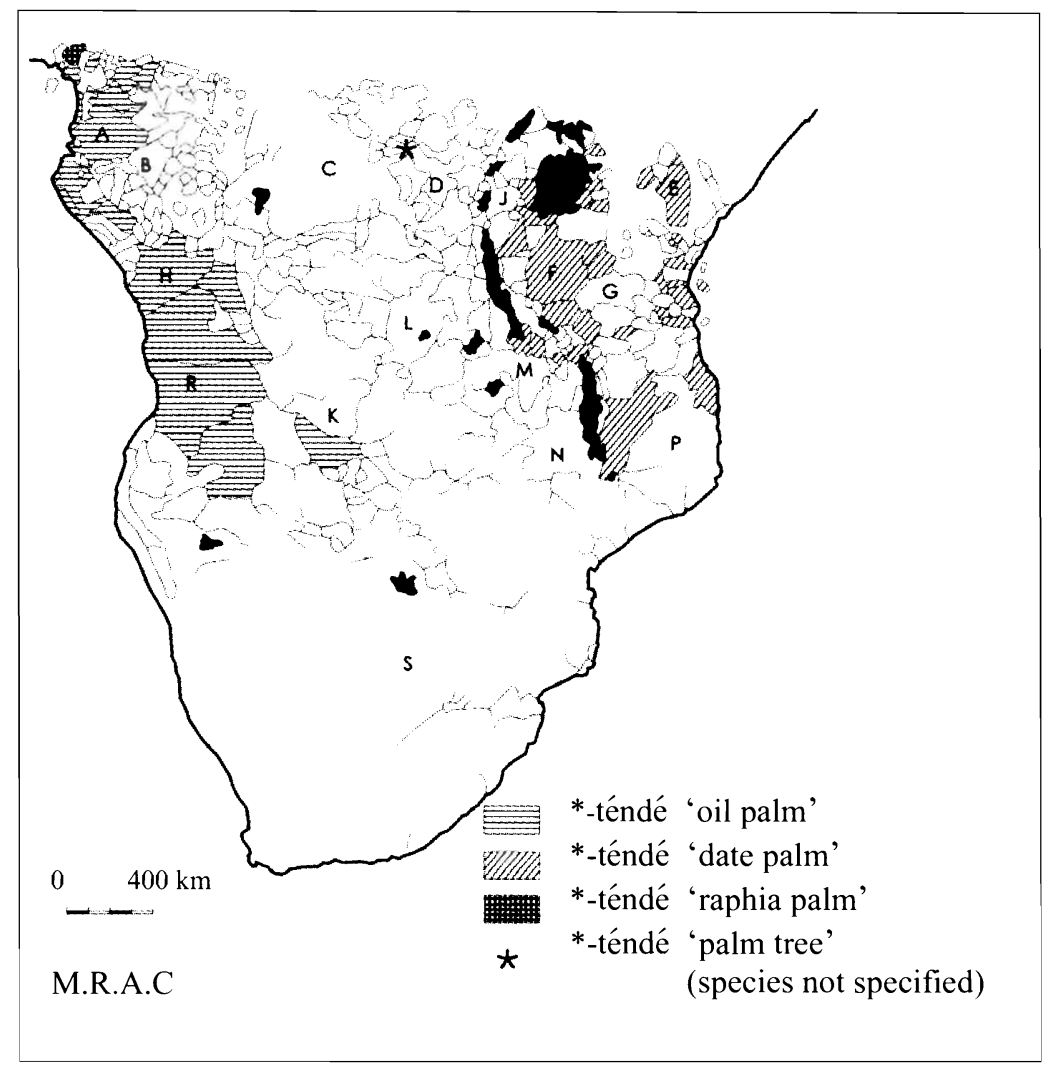

If one considers solely the distribution of the *-téndé reflexes related to the oil palm, one perceives a continuous north-south belt, which is limited to western Bantu and stretches more or less along the Atlantic coast from zone A (10-40+7080 ) through zones $\mathrm{B}(10+40)$ and $\mathrm{H}(10-30)$ into northern zone R (R11), with a slightly westward extension into the K10 group. Historically speaking, according to the Vansina (1995) classification, these reflexes thus cover the North-west subgroup of Bantu (most of zone A + B10-30) and two subgroups of the West subgroup, i.e. West Coastal (B40-80 and zone H, except H41) and South-west (zone R, most of zone K, H41, and some zone L languages). Since it occurs in two main subgroups of Bantu, it cannot be considered a regional innovation; it must be quite old. This is all the more true, if one looks upon the eastern *-téndé forms as cognates. In spite of their divergent meaning 'date palm', they are in my 
view semantically too close to be considered historical homonyms. Although the major part of these *-téndé reflexes might be the result of a recent diffusion, their origin certainly is East Bantu.

Important in this respect is the geographical gap that exists between the western and eastern attestations, which rules out the possibility of a western diffusion source for the eastern reflexes. Being attested in at least three of the main Bantu subgroups, *-téndé seems to be an appropriate candidate for reconstruction in PB. Accordingly, the early presence of *-téndé in East Bantu is in all likelihood a corollary of the first Bantu expansions in this area. It must have reached this part of the Bantu domain as a (formal) retention, which subsequently underwent a semantic innovation. This hypothesis poses a problem due to the lack of eastern *-téndé reflexes, which unmistakably manifest the assumed original meaning 'oil palm' and which could reflect a diachronic semantic stepping stone between the inherited and the new sense. The Enya (D14) reflex cited in table 4, whose translation does not permit us to identify the genus of palm tree, might constitute such a missing link. Apart from this attestation, no other (possibly) 'oil palm' related *-téndé traces have yet been discovered in East Bantu.

3.5 Other recurrent Bantu names for 'oil palm'. Throughout the text I have pointed out other oil palm related terms, which are recurrent in several Bantu languages. However, either their geographic distribution is quite limited, so that they can be seen as local innovations, or it is more scattered but at present too fragmentary, so that drawing historical conclusions would be somewhat premature. Concerning the nouns referring to the tree as such, the terms I do not treat in detail in this paper belong essentially to eastern comparative series.

The Swahili (G42) term mchikichi has lexical correspondences in several other Tanzanian languages of zones E, F, G, M, and P. The Nurse \& Philippson (1975) database reports for instance Kimbu (F24) muchikichi, 'oil palm', or Ndamba (G52) mchikichi, 'oil palm'. Given the fact that Swahili (G42)/ch/generally corresponds to $/ \mathrm{s} /$ in these languages, it can be safely assumed that these forms are loanwords from Swahili (G42). The origin of the Swahili (G42) term, which seems to be a partial reduplication, is not clear however. Anyhow, it may have replaced the ancestral term *-téndé, whose meaning shifted from 'oil palm' to 'date palm'.

Another set of recurrent terms, occuring in zones E, F, G, J, and M, seems to be related to another Swahili (G42) term for 'oil palm', i.e. muwese (Heine \& Legère 1995: 332). The correspondence is straightforward for forms such as $\mathrm{Ku}-$ ria (E43) ama-wese, 'oil palm', Nyamwezi (F21) m-ßese, 'oil palm', Ha (J66) 
ama-bese, 'palm oil', and Pimbwe (M11), um-bese, 'oil palm' (Nurse \& Philippson 1975), whose $C_{1}$ corresponds regularly to the $C_{1}$ of the Swahili (G42) form. This is less evident for several zone $\mathrm{J}$ forms, such as Kiga (J14) omu-meshe, 'oil palm', Nyambo (J21) omu-mese, 'oil palm', Haya (J22) eki-meshe, 'oil palm' (ibid.), and Shi (J53) mamesa, 'l'huile de palme' (Hostens \& Hoste n.d.: 266), where the $/ \mathrm{m} /$ in stem-initial position could be the result of the integration of a NP in the noun stem. It should be noted however that the $C_{2}$ of the Swahili (G42) noun does not regularly correspond to the $\mathrm{C}_{2}$ of all other forms. Since /ch/ is expected in Swahili (G42) when /s/ occurs in the other languages, one can suppose that the Swahili (G42) muwese is a borrowing from these languages, and not the other way around. Most of the other terms are attested in languages spoken near Lake Tanganyika. Although more data need to be considered, its origin can tentatively be situated in this region. Its presence in Swahili (G42) might then be an outcome of the caravan trade. While mchikichi spread from the coast to the interior, the diffusion of muwese probably went in the other direction.

\section{Proto-Bantu Oil Palm Vocabulary.}

This overview of the most common 'oil palm' related Bantu names leads to some interesting insights, both semantic-botanically and historical-linguistically.

With regard to botanical semantics, in-depth results are hampered by the lack of detailed data. Apart from the botanic inventories listing vernacular names, the translations are almost always limited either to the common plant name or to its scientific designation. Nevertheless, the available data show that the most common Bantu names for 'oil palm' generally refer to the most common variety of the tree, i.e. the nigrescens. In this capacity, it also serves as a generic name for all varieties of oil palm trees. In order to refer specifically to the other, less frequent varieties, this common name is modified or a distinct name is used. Some of these specific variety designations seem to be recurrent in several adjacent languages, but with exception of the ${ }^{\circ}$-koma form, they never have a supra-local distribution. The Elaeis guineensis Jacq. often being the economically most valuable palm tree, the semantic range of the most common Bantu oil palm names has been extended in some languages, to become the generic name for several kinds of palm trees. Moreover, all of them have reflexes that in certain languages exclusively refer to another kind of palm tree. However, in all cases, 'oil palm' seems to be the primary meaning from which the others ('date palm', 'raffia palm', etc.) were derived. 
For most names, such shifts are limited to rare and isolated languages. With respect to *-téndé, however, the meaning 'date palm', which is widespread in Eastern Bantu, is probably the result of historically significant semantic shift that was generalised subsequently, either through inheritance from a common ancestor or by diffusion. Finally, as the most common Bantu oil palm designations, the noun stems treated above are not only used to refer to the tree itself, but also to designate its fruits and the oil extracted from them. Noun class variation is the morphological device relied on for this type of semantic alteration. A particular noun stem may have the different meanings 'oil palm', '(bunch of) palm nuts', and/or 'oil palm' in one and the same language, but the different meanings of one particular noun may also manifest a (partially) complementary distribution. Hence, one language may have several of the most common Bantu nouns, but each of them with a different meaning, e.g. Ntandu (H16g) bá, 'nom collectif des Palmiers à stipe'; ngási, 'noix de palme', máasi, 'huile de palme'; ntééndé ba, 'jeune palmier' (Daeleman \& Pauwels 1983: 207-8).

From a historical-linguistic point of view, this study has yielded insights that differ somewhat from the preliminary conclusions advanced by Guthrie (1967-1971). The use of additional data has led to a more comprehensive idea of the geographic distribution of the noun stems considered, while the valorisation of diachronic semantic evolutions has generated a better understanding of their mutual historical relationships. Guthrie (1967-1971) observed that *-bídà, *-bá

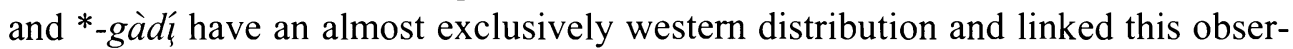
vation to the fact that the oil palm tree is a more important economic factor in this part of the Bantu area. He deemed the *-téndé C.S. too weak to draw historical conclusions from. Consequently, none of them could be considered as a PB-X item.

To start with, the geographic range of $*_{-}$gàdí is not exclusively western, even if one only takes into account the oil palm-related *-gàdí reflexes, since these occur in the Eastern Bantu zones D, F, J, L, and M, and certainly not if one establishes a diachronic link between the eastern reflexes meaning 'blood' and their western counterparts meaning 'palm oil'. It is more appropriate to see the former as semantic derivations of the latter, than to consider both sets of reflexes as originating from two historically distinct homonyms. Hence, in all likelihood this form dates back to PB (and can thus be noted with a *: *-gàdí). Similar diachronic semantically-inspired reasoning allows the reconstruction of *-téndé into PB. It is not only attested in two of the western main Bantu branches as an oil palm name, i.e. 'North-west' and 'West' according to the Vansina (1995) labels, but it also occurs in East Bantu as a designation of the date palm. 
As regards *-bídà and ${ }^{\circ}$-bá, their distribution is indeed exclusively western. Nevertheless, the former is attested in the same two western primary branches as *-téndé, i.e. 'North-west' and 'West'. Even if it has almost no eastern reflexes, this distribution suffices, in my opinion, to postulate a PB reconstruction. While the reduced economic relevance of the oil palm may have facilitated the semantic shifts that *-gàdı́ and *-téndé underwent in this part of the Bantu area, it may have induced the total disappearance of *-bídà. The presence of a *-bídà reflex in Lega (D25), generally considered as an Eastern Bantu language, seems to corroborate its status as a PB retention. As a result, amongst the four Guthrie (19671971) oil palm C.S., ${ }^{\circ}-b a ́$ is probably the only one that really is a post-PB innovation. The geographic range of its reflexes is bound to the 'West' branch. Within this main Bantu subgroup, it co-occurs with the three PB noun stems. In this part

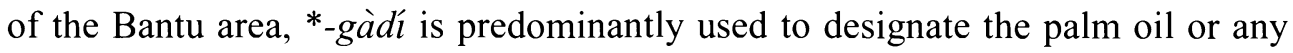
other kind of oil or fat, in some languages to designate the palm nut, but almost never to refer to the tree itself. *-téndé and ${ }^{\circ}$-bá reflexes co-exist in Kongo (H10) and Umbundu (R11). In the latter language, the available data present them as perfect synonyms. In the Kongo (H10) area, ${ }^{\circ}-b a ́$ is the generic name for (oil) palm trees, while *-téndé conveys the particular notion of a young palm tree. Accordingly, ${ }^{\circ}-b a ́$ cannot be considered an innovation having supplanted *-téndé or *-gàdí. Conversely, as stated above, it is in complementary distribution with *-bídà, almost perfectly along the lines of lexicostatistically based sub-grouping. Hence, in accordance with the claim of Guthrie (1967-1971), '-bá probably replaced *-bídà at a certain stage of the internal fragmentation of this branch. The latter has only been retained in the C50 languages and in the 'Sangha' (C10) and 'Rivers' (the northern C30 languages + C41-42) subgroups of the Vansina (1995) classification.

In sum, on the basis of the available Bantu data, *-bídà, *-téndé, and *-gàdí can be tentatively reconstructed in $\mathrm{PB}$, while ${ }^{\circ}$-bá should be considered a subsequent innovation. The meaning of the three PB noun stems was certainly related to the oil palm, but it can be questioned whether they were as synonymous as Guthrie (1967-1971) claimed. The comparative semantic analysis of the respective nouns has shown that the focal signification of each of them is slightly divergent, even if they may have identical meanings in different present-day languages. This probably indicates that their initial meaning was not identical. As I have argued above, the primary reference of * gàdi seems to be the palm nut and the oil which one extracts from it. The meaning 'oil palm', scattered within the *-gàdí distribution area but mainly attested in the most western East Bantu lan- 
guages, approximately spoken on both sides of Lake Kivu and Lake Tanganyika, probably results from subsequent (independent) semantic shifts.

As regards *-bídà and *-téndé, I have claimed that both refer primarily to the oil palm itself. This is certainly the case for the latter, whose western reflexes have this meaning almost exclusively. Through noun class variation, the *-bídà reflexes are also used to refer to the palm nut or the bunch of palm nuts. Both terms might have co-existed in $\mathrm{PB}$ as references to the tree itself. They still do, as perfect synonyms, in the Myene (B11) languages. In Nen (A44), however, *-bídà reflexes are used for the tree, its fruits and the bunch of nuts, while the *-téndé reflex refers to a young palm tree. As mentioned above, this connotation of youth turns up in other languages and dates possibly back to PB. Although both designating the tree, ${ }^{*}$-bídà and ${ }^{*}$-téndé probably were only near-synonyms in the proto-language. Nevertheless, the redundancy caused by the loss of this particular connotation may explain why the one has disappeared in favour of the other in most other present-day Bantu languages. ${ }^{29}$ Within the 'West' subgroup of the Vansina (1995) classification, the complementary distribution of both stems seems to run along genetic lines. While *-bídà is solely attested in the "Sangha" and "Rivers" subgroups, *-téndé figures in the 'West Coastal' and 'South-west' subgroups. Within the 'North-west' subgroup, the repartition of both noun stems looks to be somewhat more arbitrary. As far as the available data permit us to claim, *-téndé is the only noun stem attested in A70 and *-bídà the only one in $\mathrm{A} 60$ and B20, both are attested in separate A10, A20, A30 and A80 languages.

\section{Bantu vs. Non-Bantu Niger-Congo Oil Palm Vocabulary.}

In order to put the Bantu reconstructions just treated in a broader historical perspective, it might be worthwhile comparing them with non-Bantu Niger-Congo data. A systematic comparative study of these data is beyond the scope of this article. Nevertheless, as mentioned in the beginning of this paper, several linguists have made comparative studies of the oil palm vocabulary in non-Bantu Niger-Congo languages. In this section, I will present a summary of their reconstructions relevant in the light of our data, and I will comment on some historical relevant resemblances.

Williamson $(1970,1993)$ studied food plant names in the languages of Southern Nigeria, which apart from the Ijoid languages, belong to different sub-

\footnotetext{
${ }^{29}$ They co-exist in Akoose (A15) too, but here the *-bídà reflex refers to the oil palm, while the *-téndé reflex is the name of the raffia palm (Hedinger \& Hedinger 1982).
} 
groups of the (New) Benue-Congo branch of the Niger-Congo family. With respect to the oil palm vocabulary, just like in Bantu, she observed names that were consistent throughout a language group and could be assumed to be reconstructed to the proto-language of that group. Such was the case for other food crops believed to be indigenous to West-Africa. Given the very poor state of knowledge of the Proto-Niger-Congo sound system and its subsequent evolutions, Williamson (1993: 143) does not advance full-fledged reconstructions for oil palm names, but only presents two comparative series of resembling forms suggesting the possible existence of a common ancestral form. The first one consists of non-Bantu Benue-Congo forms possibly related to the Proto-Ijo reconstruction deku (HLH) (cf. -leg like forms cited from Cross River and Plateau languages in Williamson (1973: 258-261)), but having no corresponding attestations within Narrow Bantu. According to Williamson (1993: 143), if the Proto-Ijo form is genuinely cognate with the Benue-Congo forms, this root goes back to Proto-Atlantic-Congo. At that time, she tentatively placed Ijọid as Atlantic and Volta-Congo, the latter consisting of Kru, Kwa, Benue-Congo, Gur, Adamawa-Ubangi and possibly Dogon. The node uniting these three secondary branches, i.e. Atlantic-Congo, was a primary branch of Niger-Congo, coordinate with Mande and Kordofanian (Williamson 1989: 21).

However, the second series of Benue-Congo forms, meaning 'oil palm; palm oil' manifests strong resemblances with the $\mathrm{PB}$ reconstruction *-bídà. To cite only some examples, Crabb (1965: 83) has listed several possible Ekoid cognates, e.g. $\grave{u}$-b̂tr in Nkim, $\grave{o}-\beta \hat{\imath}$ in Bendeghe, $\grave{u}$-bì in Nta. In Tiv, ivile, 'oil-palm/ oilnut' is attested (Abraham 1940: 306). Akpes has e-bir (Ibrahim-Arirabiyi 1989) and Elugbe (1989) reconstructed A-'b'idi 'oil (palm oil)' in Proto-Edoid. Shimizu (1980: 197) advanced the Proto-Central-Jukunoid reconstruction *biT, 'oil', having reflexes such as bir in the Jibu dialect of Jukun. The author did not specify however whether it concerned palm oil. While Williamson (1973) supposed that *-bídà represented a Bantoid innovation, she more recently linked all these forms to the De Wolf (1971) Proto-Benue-Congo reconstruction *-pide, 'palm tree' and to the Proto-Ijo reconstruction pulo (Williamson 1993).

The bringing together of these reconstructions should be seen as very tentative, certainly as regards Proto-Ijo, and needs to be corroborated by solid sound correspondences. ${ }^{30}$ Nevertheless, Williamson (1993) concludes that this root is

${ }^{30}$ According to Williamson (1993: 143), the Proto-Ijo ${ }^{*} e$-bin $(\mathrm{L}-\mathrm{H})$, 'palm fruit' and the Edo $i$-vin (H-L), 'palm tree; palm kernels' might also be cognate. If this is the case, then the forms in the same languages meaning 'oil' are presumably not cognate. 
clearly Proto-Atlantic-Congo, thus rising far up in the Niger-Congo family tree. She also refers to the Mukarovsky (1976) Proto-Western-Nigritic reconstruction *-bil(a), 'oil palm; frond or nut of oil palm'. ${ }^{31}$ This reconstruction is built on the - in my opinion, shaky - association of a series of reflexes from Gur, Togo Remnant and Western Kwa languages with Guthrie's Common Bantu form *-bídà, e.g. Tenyer (Gur) mpen-ti-gi, 'oil-palm' ( $t i$-gi = 'tree'), Adele (Togo Remnant) di-bén, 'young oil palm', Awutu (Western Kwa) á-bêe, 'oil palm'. ${ }^{32}$ Given the state of knowledge of the internal relationships within Niger-Congo, such associations should be considered as highly speculative, for lack of evidence of regular sound correspondences. Amongst the numerous oil palm related vernacular names from West-African languages listed by Burkill (1997: 354-370), several items may be related to *-bídà, e.g. Akan (Kwa) $a$-b́, ' 'oil-palm'; Guere (Kru) bli, 'oil-palm'; Akpafu (Kwa) kù-bèrè, 'oil-palm'; Anyi (Kwa) ayee, 'oil-palm'; Adangme (Kwa) wie, 'oil-palm'; Konkomba (Gur) ebébirè, 'oil-palm'; Ejagham (Benue-Congo, Ekoid) obi, 'oil-palm'; Icheve (Benue-Congo, Tivoid) ò-vílè, 'oilpalm'; Igbo (Benue-Congo, Igboid) obea okporo, '(oil-palm with) thin-fleshed (nut): $f$. leucocarpa'; Edo (Benue-Congo, Edoid) ivin, 'a general term for nuts', ivin orúnmila, 'nuts of Oronmila; after an Yoruba high-priest skilled in divination'; Edo (Benue-Congo, Edoid) èfilt, 'palm oil'; Yoruba (Benue-Congo, Defoid, Yoruboid) òpè ifá, 'palm of Ifa (the god of divination)'. In sum, the PB etymon *-bídà, 'oil-palm', inherited by several present-day Bantu languages, seems to be a retention from an earlier ancestor. According to the available data, it probably reaches back to the Proto-Benue-Congo level, and perhaps beyond.

Connell (1998) focused on the yam- and palm-related vocabulary in one particular Benue-Congo subgroup, i.e. the Delta Cross languages of Southeastern

${ }^{31}$ Mukarovsky's Western Nigritic languages incorporate Western Guinean (part of Greenberg's West Atlantic), Mel (part of Greenberg's West Atlantic), Gur (Greenberg's Voltaic), Togo Remnant (part of Greenberg's Kwa), Western Kwa (part of Greenberg's Kwa) and BenueCongo (more or less the same as Greenberg's) languages. Apart from Mande and AdamawaUbangi, it roughly corresponds to Greenberg's Niger-Congo.

${ }^{32}$ Another Awutu form cited by Mukarovsky (1976) is é-wînî, 'corps', which would be cognate to Guthrie's Common Bantu reconstruction *-bìdi, 'body'. The Bantu intervocalic /1/ corresponds here to $/ \mathrm{n} /$ in Awutu. Moreover, Mukarovsky (1976) also cites the Awutu form á-bê, together with a series of similar forms from other Western Kwa languages, as a possible reflex of his Proto-Western-Nigritic reconstruction *-bá-, 'oil palm', which he associates to Guthrie's Common Bantu reconstruction *-bá. Distinguishing between the present-day reflexes of *-bá and *-bídà often being tough within Bantu, as I have commented above, it is a still more risky business between languages of different Niger-Congo subgroups. 
Nigeria. Terms for the trees themselves, as well as for frond, palm fruit, palm oil, palm kernel, broom, wine and possibly pressing were reconstructible to ProtoDelta Cross (PDC); he concluded that both the oil palm and the raffia palm were known and exploited by the speakers of that proto-language. Connell's PDC reconstructions of terms for the oil palm tree itself are interesting with respect to the Bantu vocabulary treated in this paper. Apart from *-jòb, which seems to be a Delta Cross innovation, Connell (1998: 335) has reconstructed *-dde and *-ten beyond PDC. The former, attested in the Upper Cross and Central Delta subgroups, seems to be cognate with forms found in much of Benue-Congo and beyond. The ${ }^{*}$-dde reconstruction may be related to the first comparative series listed by Williamson (1993: 143), which, as mentioned above, has no cognates within Narrow Bantu. The latter reconstruction, however, is probably related to the $\mathrm{PB}$ reconstruction *-téndé.

It is significant that Connell (1998) has reconstructed $*_{u-t \varepsilon ́ n}$ in ProtoLower-Cross with the meaning 'young oil palm', while the Proto-Ogoni *-té, and the Central Delta àtèn refer to a mature oil palm. As the author indicates, this variation between young and mature oil palm in the different Delta Cross subgroups gives evidence of semantic shift, but does not permit one to reconstruct a precise meaning in their proto-languages. Evidence for such shifting is also attested within Lower Cross, where Ushaghade útén is a general term for oil palm (Connell 1998: 335). However, in the light of the Bantu data discussed in this paper, the specific signification 'young oil palm' seems more likely. Moreover, the Delta Cross data deepen the antiquity of the term's connotation of youth, already observed within Bantu, and buttress its reconstruction in PB. As Connell (1998) rightly remarks, this reconstruction, *-ten in PDC and *-téndé in $\mathrm{PB}$, manifests a strong similarity with terms found throughout Niger-Congo. He cites the following forms: Bambara (Mande) nten, Gã (Kwa) ṫ̀̀, Mambila (Bantoid) ter. De Wolf (1971) advanced the Proto-Benue-Congo reconstruction *-tende, "palm tree', which is also given by Williamson (1973: 260). The latter refers to the Proto-Western-Nigritic reconstruction *-tandi by Mukarovsky (1976: 355), who cites the Gola (Atlantic) example má-tende, 'leaves of (raphia) palm tree' as a possible reflex. The Burkill (1997: 354-370) lists also contain several nouns whose historical relatedness with $\mathrm{PB}{ }^{*}$-téndé merits closer examination, e.g. Mandinka (Mande) téé, 'oil palm'; Maninka (Mande) tin-tulu, 'palm of oil'; Yoruba (Benue-Congo, Defoid, Yoruboid) ùdẹ, 'kernel oil'.

It is, therefore, very likely that *-téndé is older than *-bídà because it not only can be reconstructed in Proto-Benue-Congo, but, as suggested by Connell (1998), probably goes back to Proto-Mande-Congo (i.e. Niger-Congo excluding 
Kordofanian). Connell even considers the possibility that both PDC ${ }^{*}$-dde and PDC *-ten are reflexes of this old root. He refrains, however, from explaining how PDC would have acquired a double reflex of the same proto-form. Blench (forthcoming) seems to concur, uniting in one comparative series Bantu reflexes of *-téndé with would-be cognates of PDC *-dde, numerously represented in the Burkill (1997) lists, but absent from Bantu. The fact that both *-dde and *-ten can be reconstructed in one and the same proto-language, i.e. PDC, is a strong indication for two distinct (Proto?-)Niger-Congo etymons, of which only one was retained in PB.

As for the other common Bantu oil palm-related noun stems outlined in this article, there are no clear NC traces of ${ }^{*}$-gàdí beyond Bantu in the available documentation. Thus, this form, referring both to the palm nut and the oil extracted from it, is a Bantu innovation. Only Mukarovsky (1976) perceived possible reflexes of ${ }^{\circ}-b a$ a beyond Bantu. However, as noted above, the nouns he cited could also be reflexes of *-bídà. Mukarovsky based his reconstruction on the presumption that ${ }^{\circ}-b a$ is a PB form, but, as I have argued, it should be considered an innovation ulterior to $\mathrm{PB}$.

\section{Conclusions.}

This survey of non-Bantu Niger-Congo data has allowed us to put the common Bantu oil palm-related vocabulary in wider historical perspective. At least two of the terms reconstructed to PB, i.e. *-téndé, '(young) oil palm', and *-bídà, 'oil palm', have turned out to be retentions of pre-Bantu ancestors. Insofar as the present state of knowledge permits one to suggest, ${ }^{*}$-téndé seems to be the oldest term, in all likelihood dating back to a pre-Benue-Congo ancestor, maybe even to PNC, while *-bídà is probably a Benue-Congo innovation. The reconstruction of these two retentions into PB not only indicates that the speakers of the latest common ancestor of the present-day Bantu languages knew the oil palm, but also suggests that their ancestors were familiar with this tree in the distant past. However, these reconstructions do not tell us whether the oil palm was exploited in the $\mathrm{PB}$ era. More telling in this respect is the reconstruction of *-gàdi with the meaning 'palm nut; palm oil'. This points out that PB speakers knew how to use palm oil, and that they exploited the oil palm for nutritive and culinary purposes. The fact that *-gàdí does not exist beyond Bantu suggests that this practice was quite new, and not a retention from ancestral times. Of course, more detailed comparative research on Bantu terms for the associated products and the culture of the oil palm is required to draw more comprehensive historical conclusions on 
its exploitation. Nonetheless, it is pertinent to note that none of the numerous reconstructions related to the dietary aspects of the oil palm vocabulary advanced by Connell (1998) seem to reconstruct to higher than the PDC level, while the names of the tree itself are pre-PDC retentions. Just as in Bantu, this observation may indicate that the ancestors of the PDC speakers had long been familiar with the oil palm, but that only later generations began to rely on the tree in their subsistence economy.

\section{REFERENCES}

Abraham, Roy Clive. 1940. A Dictionary of the Tiv Language. Herford: Stephen Austin \& Sons.

Adam, J. 1954. Grammaire composée mbede, ndumu, duma. Brazzaville: Mémoires de l'Institut d'Etudes Centrafricaines 6.

Adams, Gustaf. 1907. "Die Sprache der Banôho". Mitteilungen des Seminars für Orientalische Sprachen 10: 34-84.

Anonym. n.d. Lokele. Manuscript. Yakusu: Boston Mission Society.

Bareau, M. \& Reding. 1912. Vocabulaire français-mobenge et mobenge-français. Bruxelles: Imprimerie Veuve Monnom.

Bastin, Yvonne. 1985. Les relations sémantiques dans les langues bantoues. Bruxelles: ARSOM, Classe des Sciences Morales et Politiques 43, 4.

Bastin, Yvonne. 1997. "Réflexions diachroniques à propos de quelques thèmes pour 'sang' en bantou." Paroles et Cultures bantoues, Mélanges en hommage à F.M. Rodegem. Tervuren: Musée royal de 1'Afrique centrale, Annales Sciences humaines vol. 159. Pp. 19-25.

Bastin, Yvonne, André Coupez, Evariste Mumba \& Thilo Schadeberg. 2003. Reconstructions lexicales bantoues 3 / Bantu Lexical Reconstructions 3. Online available database: http: //Linguistics.africamuseum.be/BLR3.html (last consultation: 15-01-2006). 
Bastin, Yvonne, André Coupez \& Michael Mann. 1999. Continuity and Divergence in the Bantu Languages: Perspectives from a Lexicostatistic Study. Tervuren: Musée royal de $1^{\prime}$ Afrique centrale, Annales, Série in- $8^{\circ}$, Sciences humaines 162.

Biton, Alexandre. 1907. Dictionnaire français-ndumu et ndumu-français, précédé d'éléments de grammaire. Franceville.

Blanchon, Jean Alain. 1994. Dictionnaire ipunu-français. Online available: http: //www.cbold.ddl.ishlyon.cnrs.fr/CBOLD_Lexicons/Punu.Blanchon1994/ (last consultation: 08-06-2005).

Blench, Roger. forthcoming. Archaeology, Language and the African Past. Lanham: Altamira Press.

Bolekia Boleka, Julio. 1991. Curso de lengua bubi. Malabo: Centro Cultural Hispano-Guineano ediciones.

Bostoen, Koen. 2004. "Linguistics for the use of African history and the comparative study of Bantu pottery vocabulary". Language and Revolution // Language and Time, ed. by Frank Brisard, Sigurd d'Hondt \& Tanja Mortelmans. Antwerp: University of Antwerp, Antwerp Papers in Linguistics. Pp. 131-54.

Bostoen, Koen. 2005. Des mots et des pots en bantou. Une approche linguistique de l'histoire de la céramique en Afrique. Frankfurt: Peter Lang, Schriften zur Afrikanistik-Research in African Studies.

Bostoen, Koen. 2006. "What comparative Bantu pottery vocabulary may tell us about early human settlement in the Inner Congo Basin". Afrique et Histoire 5: 221-263.

Botne, Robert. 1994. A Lega and English Dictionary with an Index to ProtoBantu Roots. Köln: R. Köppe, East African Languages and Dialects 5, 3.

Bourquin, Walther. 1923. Neue Ur-Bantu-Wortstämme nebst einem Beitrag zur Erforschung der Bantuwurzeln. Berlin: D. Reimer, Beihefte zur Zeitschrift für Eingeborenen-Sprachen, Heft 5. 
Burkill, H.M. 1997. The Useful Plants of West Tropical Africa. Vol. 4: Families $M-R$. Kew: Royal Botanical Gardens, $2^{\text {nd }}$ edition.

Burssens, Nico. 1993. "Lexique et texte wongo (Bandundu Z)". Annales Aequatoria 14 : 457-81.

Connell, Bruce. 1998. "Linguistic evidence for the development of yam and palm culture among the Delta Cross peoples of Southeastern Nigeria". Archaeology and Language II, Archeological Data and Linguistic Hypotheses, ed. by Roger Blench \& Matthew Spriggs. London, New York: Routledge. Pp. 324-65.

Cornet, D. 2001. "Palmier à huile (Elaeis guineensis Jacq.)". Agriculture en Afrique Tropicale, ed. by Romain Raemaekers. Bruxelles: Direction Général de la Coopération Internationale, Ministère des Affaires Étrangères, du Commerce Extérieur et de la Coopération Internationale. Pp. 812-42.

Crabb, David W. 1965. Ekoid Bantu Languages of Ogoja, Eastern Nigeria - Part I: Introduction, Phonology and Comparative Vocabulary. Cambridge: Cambridge University Press in association with the West African Languages Survey and the Institute of African Studies, Ibadan, West African language monographs 4.

Daeleman, Jan \& Luc Pauwels. 1983. "Notes d'ethnobotanique ntandu (Kongo). Principales plantes de la région de Kisaantu: noms ntandu et noms scientifiques." Africana Linguistica 9: 149-256.

Dalby, David. 1976. “The prehistorical implications of Guthrie's Comparative Bantu. Part II: Interpretation of cultural vocabulary". Journal of African History $17,1: 1-27$.

Da Silva, Maia Antonio. 1994. Dicionário Complementar Portugues-KimbunduKikongo (Linguas nativas do centro e norte de Angola). Cucujães: Editorial Missões, Cooperação Portuguesa.

De Clercq, Auguste \& Emile Willems. 1960. Dictionnaire tshiluba-français. Léopoldville: Imprimerie de la Société missionnaire de St. Paul. 
De Cort, Liaudet \& Van Goethem. 1912. Vocabulaire français-ababua et ababua-français. Bruxelles: Imprimerie Veuve Monnom.

De Wolf, Paul. 1971. The Noun Class System of Proto-Benue-Congo. The Hague: Mouton.

Downing, Laura J. 1996. The Tonal Phonology of Jita. München: Lincom Europa.

Dugast, Idelette. 1967. Lexique de la langue tunen (parler des Banen du sudouest du Cameroun). Paris: Klincksieck, Langues et littératures de l'Afrique noire.

Elugbe, Ben Ohi. 1989. Comparative Edoid: Phonology and Lexicon. Port Harcout: University of Port Harcout Press, Delta Series $N^{\circ} 6$.

Ernst, Urs. 1989. Lexique kako-français et français-kako avec tableaux de conjugaison. Yaoundé: Societe Internationale de Linguistique.

Felberg, Knut. 1996. Nyakyusa-English-Swahili and English-Nyakyusa Dictionary. Dar-es-Salaam: Mkuki na Nyota Publishers.

Fernandez, L. 1951. Diccionario español-kômbe. Madrid: Instituto de Estudios Africanos.

Goemaere, Alphonse. n.d. Spraakleer van het Londengese. Manuscript. Tervuren: Musée Royal d'Afrique Centrale.

Gossweiler, John. 1953. Nomes indigenas de plantas de Angola. Luanda: Imprensa Nacional.

Grégoire, Claire. 1976. "Le champ sémantique du thème bantou *-bánjá”. African Languages 2: 1-13.

Guerreiro, Viegas. 1963. Rudimentos de língua maconde. Lourenço Marques: Instituto de Investigação Científica de Moçambique. 
Guthrie, Malcolm. 1967-1971. Comparative Bantu: An Introduction to the Comparative Linguistics and Prehistory of the Bantu Languages, 4 vol. London: Gregg International Publishers Ltd.

Guthrie, Malcolm. 1970. Contributions from Comparative Bantu Studies to the Prehistory of Africa. In David Dalby, Languages and History in Africa, 20-49. New York: Africana Publishing Corp.

Hagendorens, Joseph. 1975. Dictionnaire otetela-français. Bandundu: CEEBA, série III, vol. 5.

Hartley, Charles W.S. 1967. The Oil Palm. London: Longman.

Hedinger, Robert \& Sylvia Hedinger. 1982. English-Akoose Wordlist. Manuscript. SIL Cameroun.

Heine, Bernd \& Karsten Legère. 1995. Swahili Plants. Köln: Rüdiger Köppe

Helmlinger, Paul. 1972. Dictionnaire duala-français, suivi d'un lexique françaisduala. Paris: Klincksieck, Langues et Littératures de l'Afrique noire 9.

Horton, Albert E. 1953. A Dictionary of Luvale. El Monte: Rhan Brothers Printing \& Lithographing Co.

Hostens \& Hoste. n.d. Dictionnaire français-shi. Manuscript. Bukavu: Centre d'étude des langues africaines.

Hulstaert, Gustaaf. 1966. Notes d'ethnobotanique mongo. Bruxelles: Académie royale des sciences d'Outre-Mer.

Ibrahim-Arirabiyi, Femi. 1989. A Comparative Reconstruction of Akpes Lects. Port Harcourt: University of Port Harcourt, Akoko North Ondo State, Ph.D. dissertation.

Iliku Mimpiya Dibata. 1979. Esquisse grammaticale de la langue tsong: phonologie et morphologie. Mémoire. Lubumbashi: UNZ. 
Jacob, Irenée. 1984. Dictionnaire rwandais-français en 3 volumes, extrait du dictionnaire de l'Institut National de Recherche Scientifique Kigali. Kigali: Imprimerie scolaire.

Kagaya, Ryohei. 1992. A Classified Vocabulary of the Bakueri Language. Tokyo: ILCAA, Bantu Vocabulary Series 8.

Kakeya, Makodo \& Nishida, Toshisada. (1976) A Glossary of Sitongwe. Manuscript.

Kawata, Ashem Tem. 2003. Bagó dictionnaire: Lingala / Falansé-Français / Lingala. Saint-Pierre-Les-Nemours: Laboratoire des langues congolaises.

Kölle, Sigismund Wilhelm. 1854. Polyglotta Africana, or a Comparative Vocabulary of Nearly Three Hundred Words and Phrases, in More than One Hundred Distinct African Languages. London: Church Missionary House.

Koloni, Jean. 1971. Eléments de morphologie et de vocabulaire de la langue enya. Mémoire. Kinshasa: Université Lovanium.

Kuperus, Juliana. 1985. The Londo Word; Its Phonological and Morphological Structure. Tervuren: Musée royal de $1^{‘}$ Afrique centrale, Annales, Série in- $8^{\circ}$, Sciences humaines 119 .

Laman, Karl Edvard. 1936. Dictionnaire kikongo-français. Bruxelles: Institut royal colonial belge, tome II.

Le Guennec, Grégoire \& Jose Francisco Valente. 1972. Dictionário PortuguêsUmbundu. Lunda: Instituto de Inverstigação Cientifica de Angola.

Leitch, Myles. 1991. Lexique Babole-Français. Brazzaville: Université Marien Ngouabi, Centre pour l'Etude des Langues Congolaises.

Mabiala, Jean-Noel. 1992. Etudes du kiyoombi, langue kongo du Congo. Mémoire. Lyon: Université Lumiere-Lyon 2.

Maley, Jean. 1999. "L'expansion du palmier à huile (Elaeis guineensis) en Afrique centrale au cours des 3 derniers millénaires: nouvelles données et 
interpretations". L'homme et la forêt tropicale, ed. by Serge Bahuchet, Daniel Bley, Hélène Pagezy \& Nicole Vernazza-Licht. Marseille: Editions de Bergier, Travaux de la Société d'Ecologie Humaine (SEH) / APFT. Pp. 237-54.

Maley, Jean \& Alex Chepstow-Lusty. 2001. "Elais guineensis Jacq. (oil palm) fluctuations in central Africa during the late Holocene: climate or human driving forces for this pioneering species?". Vegetation History and Archaeobotany 10, 2: 117-20.

Maniacky, Jacky. 2003. Tonologie du ngangela - variété du Menongue (Angola). München: Lincom Europa, Lincom Studies in African Linguistics 61.

Maniacky, Jacky. 2005. "Quelques thèmes pour « igname » en bantu". Studies in African Comparative Linguistics with Special Focus on Bantu and Mande, ed. by Koen Bostoen \& Jacky Maniacky. Tervuren: Musée royal de l'Afrique centrale. Pp. 165-89.

Meeussen, Achille Emile. 1969. Bantu Lexical Reconstructions. Tervuren: Musée Royal d'Afrique Centrale.

Meinhof, Carl. 1910. Grundriss einer Lautlehre der Bantusprachen. Berlin: Reimer \& Vohsen.

Meinhof, Carl \& Nicolaas Jacobus van Warmelo. 1932. Introduction to the Phonology of the Bantu Languages Being the English Version of 'Grundriss einer Lautlehre der Bantusprachen.' Berlin: D. Reimer, E. Vohsen.

Mertens, Joseph. 1939. Dictionnaire idzing-français suivi d'un aide-mémoire français-idzing. Bruxelles: IRCB, mémoire 4, 3.

Mickala-Manfoumbi, Roger. 2004. Lexique pové-français français-pové. Libreville: Editions Raponda Walker.

Moñino, Yves. 1995. Le proto-gbaya. Essai de linguistique comparative sur vingt et une langues d'Afrique Centrale. Paris: SELAF.

Motingea, André Mangulu. 1996. Etude comparative des langues ngiri de l'entre Ubangi-Zaïre. Leiden: CNWS. 
Motingea, André Mangulu. 2004. "The linguistic domain of the Central Congo Bassin. Uniqueness in diversity". Nature and Culture in the Democratic Republic of Congo, ed. by Els Cornelissen et al. Tervuren: Musée royal de l'Afrique centrale. Pp. 93-9.

Motte, Elisabeth. 1980. Les plantes chez les pygmées aka et les Monzombo de la Lobaye (Centrafrique). Paris: SELAF.

Mudindaambi, Lumbwe. 1977. Dictionnaire mbala-français, part. I A-fugula. Bandundu: CEEBA publications, serie III, vol. 4 a.

Mukarovsky, Hans G. 1976. A Study of Western Nigritic, Volume I. Wien: Institut für Ägyptologie und Afrikanistik, Beiträge zur Afrikanistik, Band 1-2.

Nakagawa, Hiroshi. 1992. A Classified Vocabulary of the Ha Language. Tokyo: ILCAA, Bantu Vocabulary series 9.

Ngila Bompeti, Pierre. 2000. Expérience végétale bolia (République Démocratique du Congo). Catégorisation, utilisation et dénomination des plantes. Köln: R. Köppe, Grammatische Analysen Afrikanischer Sprache Band 14.

Nguma, Wendo. 1986. Dictionnaire français-yansi (Rép. du Zaïre). Bandundu: CEEBA.

Nurse, Derek \& Philippson, Gérard. 1975. The Tanzanian Language Survey. Online database: http: //www.cbold.ddl.ish-lyon.cnrs.fr/Docs/TLS.html (last consultation: 08-06-2005).

Paas, Steven. 2004. Chichewa/Chinanja-English. Blantyre: Christian Literature Association in Malawi.

Pearson, Emil. 1973. English-Ngangela Dictionary. Morelos, Mexico: Cuernavaca. 
Philippson, Gérard. 1998. "Tone reduction vs. metrical attraction in the evolution of eastern Bantu tone systems". Theoretical Aspects of Bantu Tone, ed. by Larry M. Hyman \& Chrles Kisseberth. Stanford: CSLI. Pp. 315-29.

Philippson, Gérard \& Serge Bahuchet. 1994-1995. "Cultivated crops and Bantu migrations in Central and Eastern Africa: a linguistic approach". Azania 2930: $103-20$.

Purseglove, John William. 1972. Tropical Crops: Monocotyledons. London: Longman.

Raponda-Walker, André \& Roger Sillans. 1961. Les plantes utiles du Gabon. Encyclopédie biologique. Paris: Paul Lechevalier.

Rood, N. 1958. Ngombe-Nederlands-Frans Woordenboek. Dictionnaire ngombenéerlandais-français. Tervuren: Musée Royal d'Afrique Centrale, Sciences de l'Homme, Linguistique vol. 21.

Ruttenberg, Piet. 1969. Lexique yaka-français, français-yaka. Kinshasa.

Sacleux, Charles. 1941. Dictionnaire swahili-français, vol. 2. Paris: Université de Paris, Travaux et Mémoires de l'Institut d'Ethnologie.

Shimizu, Kiyoshi. 1980. Comparative Jukunoid: Reconstructions and Comparative Wordlists of the Jukonoid Languages, Volume II (part 2). Wien: Institut für Ägyptologie und Afrikanistik, Beiträge zur Afrikanistik, Band 5- 7.

Sowunmi, Adabisi M. 1999. "The significance of the oil palm (Elaeis guineensis Jacq.) in the late Holocene environments of West and West Central Africa: a further consideration". Vegetation History and Archaeobotany 8, 3: 199-210.

Stahl, Ann Bower. 1993. "Intensification in the West African Late Stone Age: a view from central Ghana." The Archeology of Africa. Food, Metals and Towns, ed. by Thurston Shaw, Paul Sinclair, Bassey Andah \& Alex Okpoko. London-New York: Routledge. Pp. 139-53. 
Stanley, Henry Morton. 1872. How I Found Livingstone. Travels, Adventures and Discoveries in Central Africa Including Four Months Residence with Dr. Livingstone. London: S. Low, Marston, Low, and Searle

Stappers, Leo. 1984. Lexique kisongye. Manuscript. Tervuren: Musée royal de l'Afrique centrale.

Stoop, Henk. 1977. Le lyombo, un dialecte des Topoke. Manuscript. Tervuren: Musée royal de l'Afrique centrale.

Swartenbroeckx, Pierre. 1973. Dictionnaire kikongo et kituba-français. Bandundu: CEEBA III, 2.

Thomas, Jacqueline M.C., Serge Bahuchet \& Alain Epelboin. 1993. Encyclopédie des Pygmées Aka, 4 volumes. Paris: Editions Peeters.

Thornell, Christina. 2004. "Wild plant names in the Mpiemo language". Africa and Asia 4: 57-89.

Turvey, Basil Henry Capes, Wolfgang Zimmerman \& Gabriel B. Taapopi. 1977. Kwanyama-English Dictionary. Johannesburg: Witwatersrand University Press.

Vansina, Jan. 1959. Esquisse de grammaire bushong. Tervuren: Musée royal de l'Afrique centrale.

Vansina, Jan. 1995. "New linguistic evidence and the Bantu expansion". Journal of African History 36: 173-95.

Vansina, Jan. 2004. How Societies Are Born: Governance in West Central Africa before 1600. Charlottesville: University Press of Virginia.

Van Warmelo, Nicolaas Jacobus. 1989. Venda Dictionary, Tshivenda-English. Pretoria: J.L. van Schalk.

Whitehead, John B. 1899. Grammar and Dictionary of the Bobangi Language, as Spoken over a Part of the Upper Congo West Central Africa. London: Kegan P., Trench, Trübner CO. 
Williamson, Kay. 1970. "Some food plant names in the Niger Delta". International Journal of American Linguistics 36: 156-67.

Williamson, Kay. 1973. Benue-Congo-Comparative Wordlist, Volume II. Ibadan: West African Linguistic Society.

Williamson, Kay. 1989. "Niger-Congo overview". The Niger-Congo Languages. A Classification and Description of Africa's Largest Language Family, ed. by John Bendor-Samuel \& Hartell L Rhonda. Lanham-New-York-London: University Press of America. Pp. 3-45.

Williamson, Kay. 1993. "Linguistic evidence for the use of tree and tuber food plants". The Archeology of Africa. Food, Metals and Towns, ed. by Thurston Shaw, Paul Sinclair, Bassey Andah \& Alex Okpoko. London. New York: Routledge. Pp. 139-53.

Wynne, Ronald C. 1980. English-Mbukushu Dictionary. Amersham: Avebury.

Yukawa, Yasutoshi. 1984. A Classified Dictionary of the Sambaa Language. Tokyo: ILCAA, Asian and African lexicon 15.

Ziervogel, Dirk \& Pothinus C. Mokgokong. 1975. Groot Noord-Sotho Woordenboek, Comprehensive Northern Sotho Dictionary. Pretoria: Van Schaik Ltd/Unisa.

African Linguistics

Royal Museum for Central Africa

3080 Terveuren, Belgium

koen.bostoen@africamuseum.be [received November 10, 2005 accepted January 11, 2006] 